\title{
Origin of the Coloured Karst Fills in the Neogene Extensional System of NE Iberia (Spain)
}

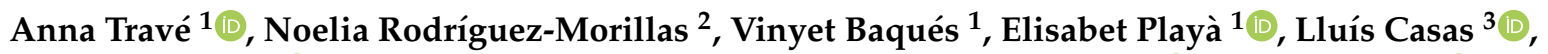

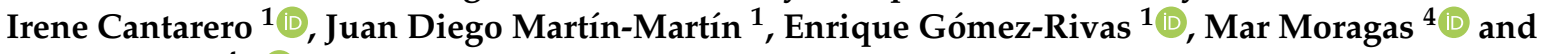 \\ David Cruset ${ }^{4, *}$ (1)
}

1 Departament de Mineralogia, Petrologia i Geologia Aplicada, Facultat de Ciències de la Terra, Universitat de Barcelona (UB), 08028 Barcelona, Spain; atrave@ub.edu (A.T.); vinyetb@gmail.com (V.B.); eplaya@ub.edu (E.P.); i_cantarero@ub.edu (I.C.); juandiegomartin@ub.edu (J.D.M.-M.); e.gomez-rivas@ub.edu (E.G.-R.)

2 Repsol Technology Lab., 28935 Móstoles, Spain; noelia.rodriguez@repsol.com

3 Departament de Geologia, Universitat Autònoma de Barcelona (UAB), Edifici C, Cerdanyola del Vallès, 08193 Catalonia, Spain; lluis.casas@uab.cat

4 Group of Dynamics of the Lithosphere (GDL), Geosciences Barcelona (GEO3BCN-CSIC), Lluís Solé i Sabarís s/n, 08028 Barcelona, Spain; mmoragas@geo3bcn.csic.es

* Correspondence: dcruset@geo3bcn.csic.es

\section{check for} updates

Citation: Travé, A.; Rodríguez-Morillas, N.; Baqués, V.; Playà, E.; Casas, L.; Cantarero, I.; Martín-Martín, J.D.; Gómez-Rivas, E.; Moragas, M.; Cruset, D. Origin of the Coloured Karst Fills in the Neogene Extensional System of NE Iberia (Spain). Minerals 2021, 11, 1382. https://doi.org/10.3390/min11121382

Academic Editors: Georgia Pe-Piper and Roberta Di Febo

Received: 29 October 2021

Accepted: 30 November 2021

Published: 8 December 2021

Publisher's Note: MDPI stays neutral with regard to jurisdictional claims in published maps and institutional affiliations.

Copyright: (c) 2021 by the authors. Licensee MDPI, Basel, Switzerland. This article is an open access article distributed under the terms and conditions of the Creative Commons Attribution (CC BY) license (https:// creativecommons.org/licenses/by/ $4.0 /)$.
Abstract: Karst fills from the onshore Penedès Basin and offshore València Trough display red, pink, orange and ochre colours. Their Mössbauer spectra indicate that $\mathrm{Fe}^{3+}$ contained in goethite is the dominant species in reddish-pink fills, whereas $\mathrm{Fe}^{2+}$ contained in dolomite and clays is more dominant in the orange and ochre ones. The lower $\delta^{13} \mathrm{C}$ values and higher ${ }^{87} \mathrm{Sr} /{ }^{86} \mathrm{Sr}$ ratios of the karst fills with respect to their host carbonates can reflect the input of soil-derived $\mathrm{CO}_{2}$ and an external radiogenic source into the karst system. This geochemical composition, together with the non-carbonate fraction of the fills, consists of authigenic and transported illite, illite-smectite interlayers, as well as kaolinite, chlorite, pyrite, quartz, ilmenite, magnetite, apatite and feldspar, account for a mixed residual-detrital origin of fills. This polygenic origin agrees with that of the terra rossa sediments described worldwide. The different colours of karst fills are attributed to fluctuations in the water table, which control the $\mathrm{Eh} / \mathrm{pH}$ conditions in the karst system. Thus, reddish colours reflect low water table levels and oxidising episodes, and orange and ochre ones reflect high water table levels and more reducing episodes. The greenish colours of fills could be related to fluctuations in the $\mathrm{Fe}^{3+} / \mathrm{Fe}^{2+}$ ratio.

Keywords: carbonate diagenesis; coloured karst fills; fracture and vug porosity; geochemistry

\section{Introduction}

Karst sediments register the evolution of karst systems developed in carbonate rocks [1]. In this regard, their geochemical composition can provide information about changes in climate, groundwater level fluctuations and tectonic regimes within orogens and sedimentary basins [2-6].

Coloured sediments within karstified rocks are widely recognised worldwide. Red sediments such as terra rossa deposits and laterites have been widely attributed to residual soil deposits due to rock weathering [7], although detrital inputs are also reported in terra rossa sediments. Examples of such deposits have been documented in karst systems from the Czech Republic and Slovenia [1], South Africa [8] and in the Northern Apennines [9,10]. Beige to pink rocks found in calcretes developed on quaternary karstic surfaces in the Grand Cayman Island were interpreted as resulting from a porous mixture of dolomite, clay and calcite due to the activity of plant roots and associated microorganisms [11]. Dark to black colours are attributed to the presence of organic matter transported by groundwater 
flows, which hides their original red or brownish colour, as observed in the coastal caves of Mallorca Island [12].

The onshore Penedès Basin (Catalan Coastal Ranges) and the offshore València Trough (Western Mediterranean) are part of the same extensional system that affected the NE sector of Iberia during the latest Oligocene and Miocene [13]. Several diagenetic studies were carried out in these areas motivated by the oil exploitation potential of offshore carbonate reservoirs [3,14-18]. These authors deciphered the fracture and fluid flow history in structural highs and normal fault zones, defining different diagenetic events related to the tectonic evolution of the Penedès Basin and València Trough from the Mesozoic to the Neogene. Multiple karst events were identified in Mesozoic limestones and dolostones in close association with the Neogene extension [3,15-21]. Karstification comprises dissolution processes, calcite and dolomite cementation from meteoric fluids, and are characterised by carbonate karst fills displaying red, pink, orange, ochre and green colours.

Despite the existing knowledge about the geology of the onshore Penedès Basin and the offshore València Trough, several questions about karst fills remain open: (1) the residual vs. detrital origin of the fills, (2) their accurate mineralogical composition, (3) the redox conditions in which they were deposited and/or precipitated and (4) the significance of their variable colour. To shed light on these issues, we combined petrographic observations with Mössbauer spectrometry, classical isotopic methods $\left(\delta^{18} \mathrm{O}, \delta^{13} \mathrm{C}\right.$ and $\left.{ }^{87} \mathrm{Sr} /{ }^{86} \mathrm{Sr}\right)$ and elemental composition analyses (electron microprobe). The results enlighten the current knowledge of the evolution of karst systems in carbonate rocks from the Western Mediterranean Margin during the Neogene rift-related extension and equivalent systems worldwide.

\section{Geological Setting}

The Penedès Basin and the València Trough are linked to the Palaeogene to Neogene tectonic evolution of the Catalan Margin, which consists of a portion of the Western Mediterranean Margin. This margin displays a horst and graben structure that formed during the latest Oligocene to Miocene extension [22,23], resulting from the reactivation of previous Eocene to late Oligocene compressional fractures [24-26] (Figure 1A). The Penedès Basin, together with its northeastern continuation, the Vallès Basin, as well as the El Camp and Amposta Basins, are all NE-SW half grabens that compartmentalised the onshore Western Mediterranean Margin and defined a system of NE-SW system of horsts known as the Catalan Coastal Ranges [13]. These ranges represent the northern margin of the València Trough, which is bounded to the south by the Betic orogen [27]. The offshore València trough displays a similar structure to the Catalan Coastal Ranges, with a system of structural highs limited by extensional basins (e.g., Tarragona and Barcelona Basins) [13].

In the Penedès Basin and València Trough, Upper Jurassic and Lower Cretaceous marine limestones and dolostones act as structural highs and basement of the latest PalaeogeneNeogene sediments filling the extensional basins [13] (Figure 2). In general, the stratigraphy of the Penedès Basin comprises: (1) Aquitanian to lower Burdigalian alluvial and lacustrine sediments, (2) middle Burdigalian sabkha-salina deposits, (3) upper Burdigalian to Langhian shelf deposits and (4) Langhian to middle Serravallian fan delta deposits, which laterally pass to continental complexes that were accumulated until the Tortonian [28,29]. These sediments are truncated by an erosive event related to the Messinian, which was followed by the deposition of Pliocene marine and alluvial sediments.

A summary of the stratigraphy of the València Trough was presented by [15] (Figure 2). Rift-related sedimentation began with the deposition of Chattian to Aquitanian red beds, conglomerates and dolostones (Basal Tertiary Group), which are unconformably overlain by Burdigalian-Langhian dark to black argillaceous limestones with variable organiccarbon content (Casablanca Group). These sediments are the main source of rock of the Casablanca oil field in the València Trough [30,31]. Source rocks of the Casablanca Group are overlain by Serravallian turbidites of the Sant Carlos Group and/or limestones and marls of the Castellón Group, which in turn are overlain by Tortonian to Messinian shales. 
These shales acted as a regional seal. Younger sediments consist of Plio-Quaternary shelf sandstones and conglomerates of the Ebro Group [32].
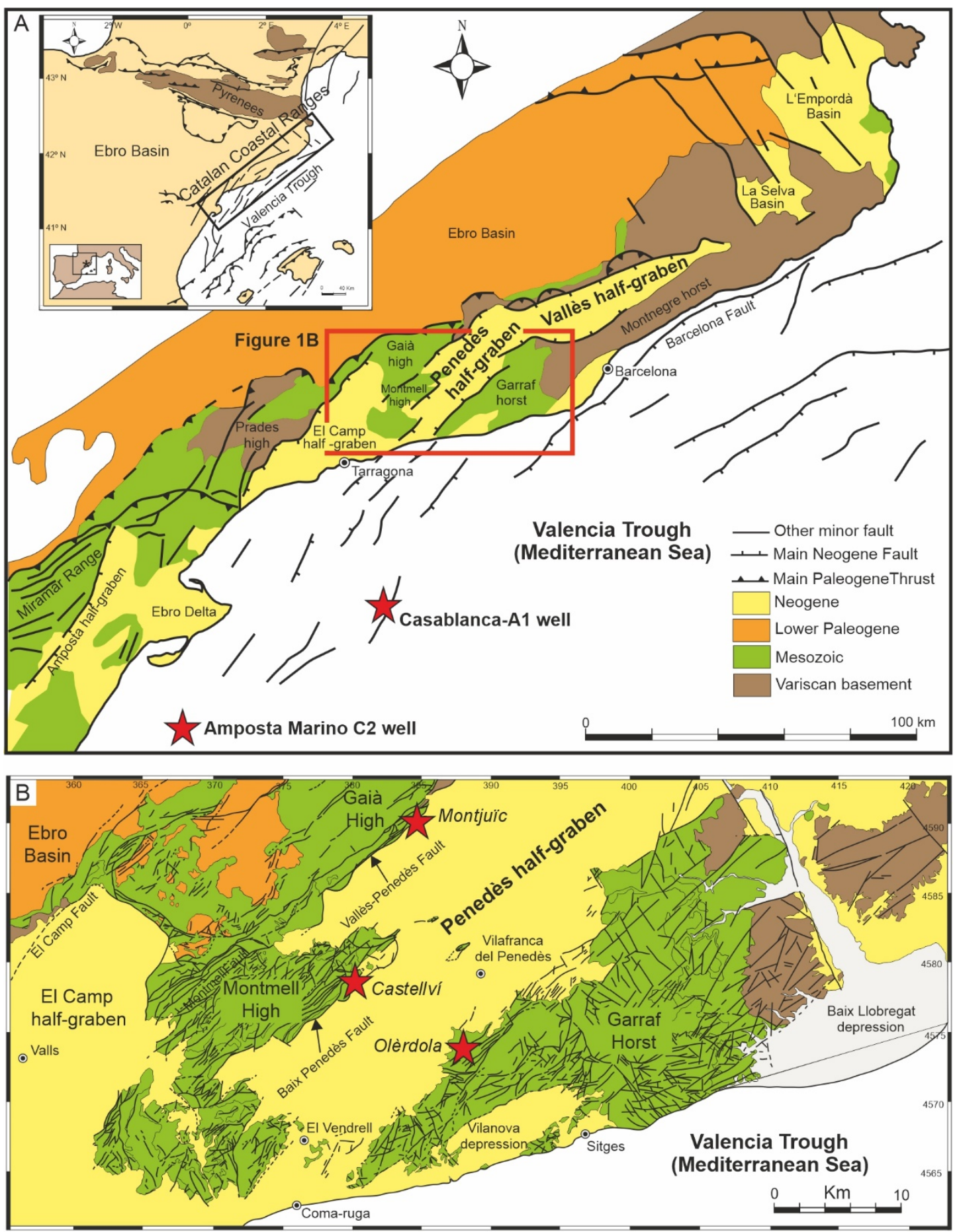

Figure 1. (A) Simplified geological map of the Catalan Coastal Ranges and location of the Casablanca-1A and Amposta Marino C2 wells in the València Trough (red stars). The red box indicates the location of Figure 1B. (B) Geological map of the Penedès half-graben showing location of the Castellví, Olèrdola and Montjuïc outcrops (red stars). Redrawn from [3]. 

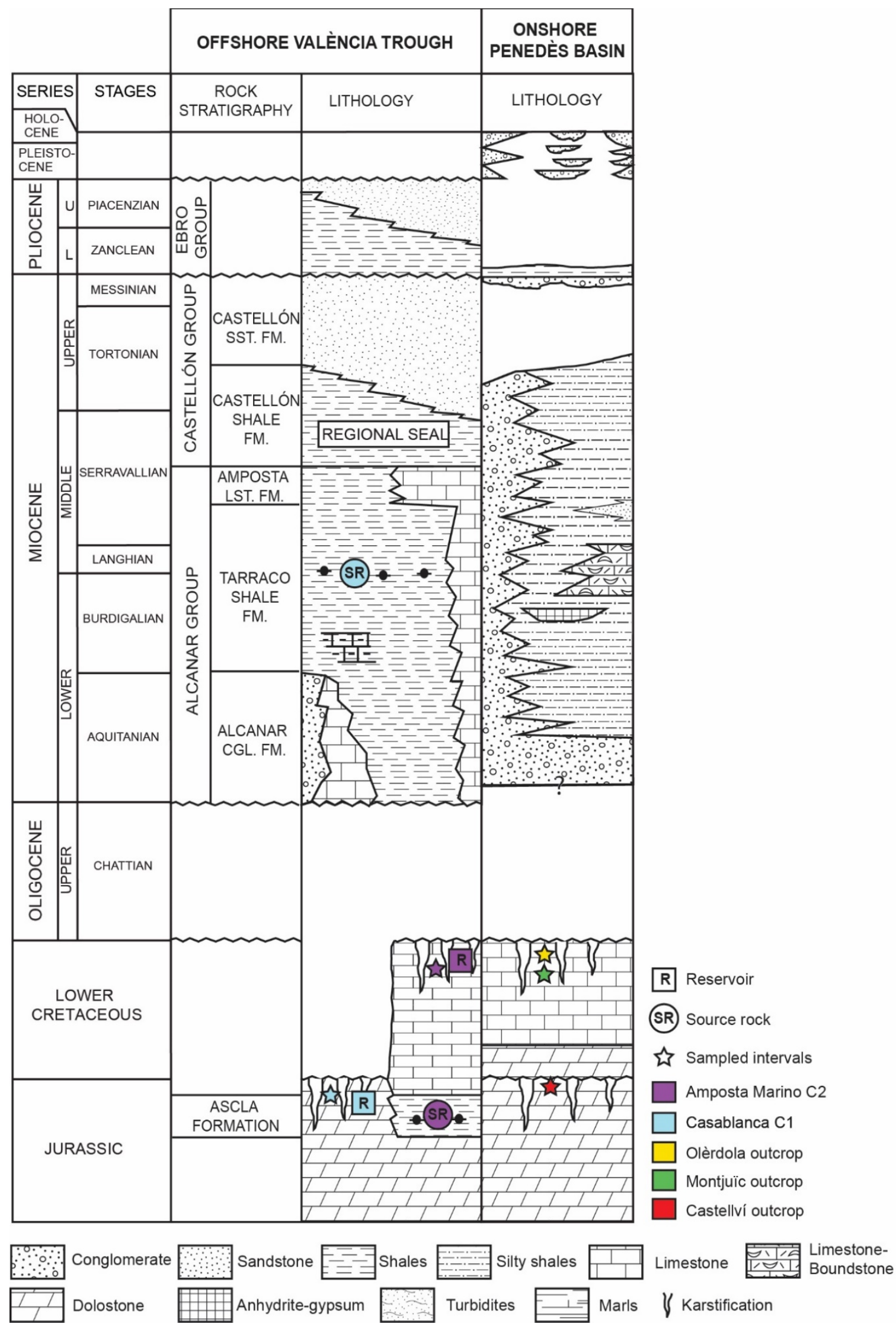

Figure 2. Lithostratigraphy of the offshore València Trough and onshore Penedès Basin. The stratigraphy of the València Trough is based on the lithostratigraphic panels of [15,16], as well as the cross-section of [33]. The stratigraphy of the Penedès Basin is based on the lithostratigraphic panel in [34]. 


\section{Study Areas}

The studied karst fills are found in the porosity of Mesozoic carbonate rocks in both the offshore València Trough and in the onshore Penedès Basin [3,15-18,21]. They were described by previous authors in the Casablanca-1A and Amposta Marino C2 wells (València Trough) and in the Montjuïc, Castellví and Olèrdola outcrops of the Penedès Basin (Figure 1).

\subsection{Casablanca-1A Well}

The Casablanca oil field is $1 \mathrm{~km}$ wide and $11 \mathrm{~km}$ long and is located in a structural high formed by Mesozoic carbonate rocks. This palaeohigh is limited by normal faults in its northwestern and southeastern margins [20]. In the Casablanca oil field, the main reservoir rocks are Upper Jurassic and Lower Cretaceous shallow marine limestones and dolostones.

The study of the diagenetic evolution of the Casablanca oil field was carried out by [15] in samples from the Casablanca-1A well. This well cuts $100 \mathrm{~m}$ of karstified Upper Jurassic (Kimmeridgian) dolostones, where karstic matrix- and clast-supported collapse breccias, vug and fracture porosities are filled with ochre and red dolomite fills (RD2 sediment according to the terminology used in [15]). According to these authors, the Jurassic host rocks forming the Casablanca oil field were affected by three main diagenetic stages: (1) karstification and karst fill accumulation, (2) dolomitisation of both host carbonates and karst fills and (3) calcite cementation and oil emplacement.

\subsection{Amposta Marino C2 Well}

The Amposta oil field consists of a $25 \mathrm{~km}$ long Mesozoic structural high, bound by normal faults and covered by Neogene sediments [35]. In the Amposta Marino C2 well, samples from $1874 \mathrm{~m}$ to $1957 \mathrm{~m}$ depth were studied. This well cuts locally-karstified Barremian-Aptian limestones that are overlain by Miocene clays, sandstones and conglomerates. In the Barremian-Aptian limestones, several fracture, cementation and karstic events were reported by [16]. According to these authors, in the Amposta Marino C2 well, three main types of fracture systems $(\mathrm{A}-\mathrm{C})$ and four types of calcite cement are present. Fractures A and B are completely filled with calcite cement. Fractures A correspond to pre-Alpine structures, whereas fractures $B$ are attributed to being developed during the late Eocene-early Oligocene Alpine compression. Fractures C, developed during the Neogene extension and enlarged by subaerial exposure, are filled with karst fills constituted of microsparite, clays and blocky calcite cement, which are postdated by kaolinite, pyrite, barite and oil.

\subsection{The Penedès Basin}

In the onshore Penedès Basin, Upper Jurassic and Lower Cretaceous carbonate sequences are well exposed at the tilted fault blocks, where their uppermost is affected by fractures enlarged by karstic dissolution, vug porosities and large caverns. Several palaeokarst horizons developed onshore since the lower Eocene [3,7,36,37].

Vug, cavern and fracture porosities described by previous authors are occluded with reddish to ochre laminated fills and by sparite calcite cement. These karst fills and cements are summarised and described in detail by $[3,17,18]$. For the present study, we chose the Montjuïc, Castellví and Olèrdola outcrops, where excellent exposures of karst fills are observed. The Montjuic outcrop is constituted by Barremian lacustrine limestones, the Castellví outcrop corresponds to the Thitonian-Berriasian Garraf Upper Dolomites Formation and the Olèrdola outcrop corresponds to marine limestones of the lower Aptian Farreny Formation [36]. In these three outcrops, the studied karst fills are filling randomlyoriented fractures (Castellví and Olèrdola) and vugs (Castellví), as well as the intraclast porosity of fault breccias (Montjuï) and breccias that result from the collapse of randomlyoriented fractures (Olèrdola). 


\section{Materials and Methods}

Part of the results presented in this study was already presented in [3,15-18]. These results are combined with new petrographic, spectral and isotopic and elemental compositions and are summarised in Table 1. A description of the different petrographic, spectral and elemental and isotopic methods of analysis are presented in this section.

Table 1. List of analytical methods used in this work and the areas where they were applied. Data from this work and from previous authors are also indicated.

\begin{tabular}{|c|c|c|c|c|c|c|}
\hline $\begin{array}{c}\text { Studied } \\
\text { Outcrop/Well }\end{array}$ & $\begin{array}{l}\text { Optical and Cathodolumi- } \\
\text { nescemicroscope }\end{array}$ & $\begin{array}{l}\text { SEM, } \\
\text { TEM }\end{array}$ & XRD & $\begin{array}{l}\text { Mössbauer } \\
\text { Spect. }\end{array}$ & $\begin{array}{l}\text { Electron Microprobe, } \\
\delta^{18} \mathrm{O}, \delta^{13} \mathrm{C}\end{array}$ & ${ }^{87} \mathrm{Sr} /{ }^{86} \mathrm{Sr}$ \\
\hline \multicolumn{7}{|c|}{ València Trough } \\
\hline Casablanca-1A & [15] & This work & [15] & This work & [15] & [15] \\
\hline $\begin{array}{l}\text { Amposta } \\
\text { Marino C2 }\end{array}$ & [16] & - & - & - & [16] & [16] \\
\hline \multicolumn{7}{|c|}{ Penedès Basin } \\
\hline Castellví & [3], this work & - & This work & This work & [3] & [3] \\
\hline Olèrdola & This work & - & - & - & This work & - \\
\hline Montjuïc & This work & - & This work & This work & This work & - \\
\hline
\end{tabular}

A total of thirty-one samples from the Casablanca-1A well core at depths between $2660 \mathrm{~m}$ and $2760 \mathrm{~m}$; twenty-three samples from the Amposta Marino C-2 well, at perforation depths between 1874 and 1957 m; and more than 240 samples from the Penedès Basin outcrops were carefully studied in order to identify the diagenetic phases and their spatial and temporal relations. The selected karst fills for this study are in Jurassic and Early Cretaceous carbonates, although they are interpreted to have occurred during the Neogene rift-related extension affecting the North Eastern Margin of Iberia [3,15-21]. Thin sections were examined using optical and cathodoluminescence (CL) microscopy (Technosyn Cold Cathodoluminescence Model 8200 MkII (Technosyn Limited, Cambridge, UK) operating at 10-18 kV gun potential and 250-350 $\mu \mathrm{m}$ beam current). For scanning electron microscopy (SEM), an ESEM Quanta 200 FEI, XTE 325/D8395 device (FEI Europe B.V., Eindhoven, The Netherlands) with an energy dispersive spectrometer (EDX) and equipped with backscatter image technology was used. For Transmission electron microscopy (TEM), a JEOL $1010+$ Orius (Gatan) device with a CCD camera was used.

For the detailed study of the non-carbonate fraction, the bulk rock was leached with $\mathrm{HCl} 10 \%$ at room temperature. The resulting non-carbonate fraction was analysed with X-ray diffraction (XRD), with a diffractometer Siemens D-500 (Bruker AXS, Karlsruhe, Germany) working at $40 \mathrm{kV}$ and $30 \mathrm{~mA}$, and equipped with a graphite monochromator. The whole rock mineralogy of the non-carbonate fraction was obtained from non-oriented powdered preparations. The mineralogy of the clay fraction was obtained from oriented aggregates in air-dried etilenglicol (ETG) and heated at $550{ }^{\circ} \mathrm{C}$ preparations.

Selected samples of host rocks and dolomite and calcite, contained in the ochre, reddish, green and orange karst fills were used to characterise the oxidation state of Fe by determining the $\mathrm{Fe}^{2+} / \mathrm{Fe}^{3+}$ ratio by Mössbauer spectrometry (MS). The ${ }^{57} \mathrm{Fe}$ Mössbauer spectra were acquired at room temperature by means of a conventional spectrometer with an operation geometry of transmission and radioactive source of ${ }^{57} \mathrm{Co}$ in an Rh matrix. The spectra were calibrated with a standard iron foil. The isomeric shifts are given with respect to the isomeric shift of this sample standard.

In order to analyse major, minor and trace element composition ( $\mathrm{Ca}, \mathrm{Mg}, \mathrm{Mn}, \mathrm{Fe}, \mathrm{Sr}$ and $\mathrm{Na}$ ) of the diagenetic products, eight $\mathrm{C}$-coated double-polished thin sections were investigated. The analyses were performed using a CAMECA SX-50 electron microprobe (CAMECA SAS, Gennevilliers, France), equipped with four vertically oriented WD X-ray spectrometers and operating at $20 \mathrm{kV}$ of excitation potential, with $10 \mu \mathrm{m}$ of beam diameter and $10 \mathrm{nA}$ of current intensity for the $\mathrm{Ca}$ and $\mathrm{Mg}$ analyses, and $50 \mathrm{nA}$ for $\mathrm{Mn}, \mathrm{Fe}, \mathrm{Sr}$ and $\mathrm{Na}$. The detection limits are $495 \mathrm{ppm}$ for $\mathrm{Ca}, 493 \mathrm{ppm}$ for $\mathrm{Mg}$, $131 \mathrm{ppm}$ for Mn, $128 \mathrm{ppm}$ 
for $\mathrm{Fe}, 161 \mathrm{ppm}$ for $\mathrm{Sr}$ and $128 \mathrm{ppm}$ for $\mathrm{Na}$. Na and Mn are mostly under the detection limit in all the identified diagenetic products. Standards used were calcite for $\mathrm{Ca}$, periclase for $\mathrm{Mg}$, albite for $\mathrm{Na}$, celestite for $\mathrm{Sr}$, iron oxide for Fe and rhodonite for $\mathrm{Mn}$. Precision on major element analyses averaged $6.86 \%$ standard error at $3 \sigma$ confidence level.

For carbon- and oxygen-isotope analyses, samples were prepared using a $500 \mu \mathrm{m}$-thick microdrill to extract $60 \pm 10 \mu \mathrm{g}$ of powder from trims containing carbonate host rocks and karst fills. The carbonate powder was reacted with $100 \%$ phosphoric acid for two minutes at $70{ }^{\circ} \mathrm{C}$ for calcite. The resultant $\mathrm{CO}_{2}$ was analysed using an automated Kiel Carbonate Device attached to a Thermal Ionization Mass Spectrometer Thermo Electron (Finnigan) MAT-252 (Thermo Fisher Scientific, Bremen, Germany) following the method of [37]. The obtained results were corrected using the standard technique from [38,39], expressed in \%o with respect to the VPDB (Vienna Pee Dee Belemnite) standard. The standard deviation is $\pm 0.01 \%$ or $\delta^{13} \mathrm{C}$ and $\pm 0.05 \%$ o for $\delta^{18} \mathrm{O}$.

Samples of $100 \%$ calcite and dolomite were analysed for ${ }^{87} \mathrm{Sr} /{ }^{86} \mathrm{Sr}$. Samples were fully dissolved in $5 \mathrm{~mL}$ of $10 \%$ acetic acid and introduced in an ultrasonic bath for $15 \mathrm{~min}$. After this time, samples were centrifuged for ten minutes at $4000 \mathrm{rpm}$ and dried. The resultant product was reacted in $1 \mathrm{~mL}$ of $3 \mathrm{M} \mathrm{HNO}_{3}$ and dried. Finally, the sample was digested again in $3 \mathrm{~mL}$ of $3 \mathrm{M} \mathrm{HNO}_{3}$ and introduced in chromatographic columns. For the chromatographic separation of $\mathrm{Sr}$, an extraction resin type SrResinTM was used (Trisken International, London, UK) (crown ether (4.4' (5')-di-t-butylcyclohexano-18-crown-6). The $\mathrm{Sr}$ was recovered with $\mathrm{HNO}_{3} 0.05 \mathrm{M}$ as eluent. The fraction where $\mathrm{Sr}$ is concentrated was dried, charged on a Re single filament with $1 \mu \mathrm{L}$ of $\mathrm{H}_{3} \mathrm{PO}_{4} 1 \mathrm{M}$ and $2 \mu \mathrm{L}$ of $\mathrm{Ta}_{2} \mathrm{O}_{5}$ and analysed on a TIMS-Phoenix mass spectrometer (Isotopx, Cheshire, UK). The data acquisition method consisted of dynamic multicollection during ten blocks of 16 cycles each one, with a beam intensity in the ${ }^{88} \mathrm{Sr}$ mass of $3 \mathrm{~V}$. Analyses were corrected for possible interferences of ${ }^{87} \mathrm{Rb}$. The ${ }^{87} \mathrm{Sr} /{ }^{86} \mathrm{Sr}$ ratios were normalised with respect to the measured mean value of the ratio ${ }^{86} \mathrm{Sr} /{ }^{88} \mathrm{Sr}=0.1194$ of the isotopic standard NBS-987 in order to correct possible mass fractionation during filament charge and instrumental analyses. The precision of the analytical standard error or internal precision is 0.000003 .

\section{Petrology of Host Carbonates and Karst Fills}

The paragenetic sequence of fracture-filling calcite and dolomite cement, as well as karst, fills in the offshore València Trough and onshore Penedès Basin was already established by [3,15-18]. With the aim of facilitating the comparison with previous studies, this work uses the same terminology used by [16] and [3,17,18] for the Amposta Marino C2 well, and for the Castellví and Olèrdola outcrops in the Penedès Basin, respectively. For the Casablanca C1 well, the dolomite host rocks and karst fills described by [15] are called Dolomite 1 (RD1) and Dolomite 2a and 2b (RD2) in this study. For the Montjuïc outcrop in the Penedès Basin, the orange matrix made of orange pisoids described by [3] is called OP1 in this study. The host rocks and karst fills are listed in Table 2.

Table 2. List of host rocks and karst fills from the offshore València Trough and the onshore Penedès Basin.

\begin{tabular}{cccccc}
\hline Area & Studied Outcrop/Well & Fill & Host Rock & Colour & Mineralogy \\
\hline València Trough & Casablanca-1A & Dolomite 2b & Dolomite 2a & Red and ochre & Dolomite \\
València Trough & Amposta Marino C2 & CS3r & Limestones & Red & Calcite \\
València Trough & Amposta Marino C2 & CS3g & Limestones & Green & Calcite \\
Penedès Basin & Castellví & DS2 & RD1 & Orange & Dolomite \\
Penedès Basin & Castellví & DS3 & RD1 & Pink to red & Pink \\
Penedès Basin & Castellví & CS1 & RD1 & Calcite \\
Penedès Basin & Olèrdola & CS2 & Limestones & Calcite \\
Penedès Basin & Olèrdola & CS3 & Limestones & Red Calcite \\
Penedès Basin & Montjuìc & OP1 & Limestones & Orange & Calcite \\
\hline
\end{tabular}




\subsection{Casablanca-1A Well}

The diagenetic study of the Casablanca-1A well was carried out by [15]. The original host rock porosity was totally occluded in this well by multiepisodic dolomitisation processes. At present, the porosity is estimated to range between $7 \%$ and $12 \%$ [33], with most being of secondary origin (vug, intercrystalline, fracture and mouldic). Vug porosity up to $2 \mathrm{~cm}$ can be partially filled with dolomitised fills displaying geopetal structures. Fracture porosity corresponds to vertical fractures totally or partially occluded by calcite and dolomite cement, or karst fills.

The Upper Jurassic (Kimmeridgian) host dolostones are formed by replacive dolomite with a crystal size of $10 \mu \mathrm{m}$ to $80 \mu \mathrm{m}$. Dolomite 1 forms hypidiotopic crystal mosaics and shows a penetrative and destructive fabric. The crystals are non-homogeneous bright red under cathodoluminescence (Figure $3 \mathrm{~A}, \mathrm{~B}$ ). Dolomite 1 is only preserved as centimetric patches isolated between Dolomite 2a.

Dolomite 2a replaces Dolomite 1. It consists of a mosaic of hypidiotopic crystals, with a size from 20 to $140 \mu \mathrm{m}$, and with a penetrative and non-destructive fabric. Dolomite 2a crystals are zoned, with dark cores and clear outer zones, and have dull red cathodoluminescence (Figure $3 \mathrm{~A}, \mathrm{~B}$ ). Some crystals have a core with a luminescence typical of Dolomite 1.

Replacive Dolomite $2 \mathrm{~b}$ replaces the karst fills in the fracture and vug porosity within the host dolostone. It consists of euhedral crystals, $40 \mu \mathrm{m}$ to $450 \mu \mathrm{m}$ in size and planar-e borders, forming a dense fabric-selective idiotopic mosaic (Figure 3C,D). The crystals have a dark nucleus and clear outer zones, and dull red luminescence. Only locally, some of the zones are bright orange. Two types of Dolomite $2 b$, characterised by two different colours, fills fracture and vug porosity. The first one evolves from pink to red colour, travelling through to reddish-brown (Figure 3E). The second has a very pale brown or clear grey olive colour (Figure 3F). In this work, the first one is called a reddish fill, and the second one is an ochre fill. Dolomite $2 \mathrm{~b}$ is only present in the uppermost $15 \mathrm{~m}$ of the Casablanca-1A well [15]. SEM and TEM microscopy reveal that the non-carbonate fraction of Dolomite $2 \mathrm{~b}$ consists of illite, pyrite and goethite, although XRD performed previously by [15] also indicates the presence of illite/smectite (Figure 4A). Illite is observed in both the ochre and red fills and occurs as (1) clay coatings of dolomite flaky crystals with irregular shape (Figure 5A,B) and (2) as lath-shaped crystals (Figure 5C). Pyrite and ilmenite are also observed in the ochre and reddish fills, occluding growth cavities of dolomite or disseminated between dolomite crystals (Figure 5D,E). Goethite and magnetite are also identified in the reddish Dolomite $2 \mathrm{~b}$ (Figure 5F), whereas apatite is observed in the ochre one.

\subsection{Amposta Marino C2 Well}

The fluid flow history of the Amposta oil field rocks was deciphered by [16]. In this well, the Lower Cretaceous host limestones (usually brecciated) are wackestones to packstones of benthic foraminifera, silicified sponge spicules, green algae and echinoderm fragments that show a dull-red luminescence. Foraminifera mainly consists of Orbitolinopsis, Nautiloculina, Pseudocyclamina, Choffatella and miliolids. The uppermost part of the sampled interval is a wackestone of charophytes-Atoporochara, ostracoda and dasycladacea algae characterising freshwater and shallow marine facies. Small framboidal pyrites are disseminated in the host-limestones or concentrated in the stylolitic planes as insoluble residue. 

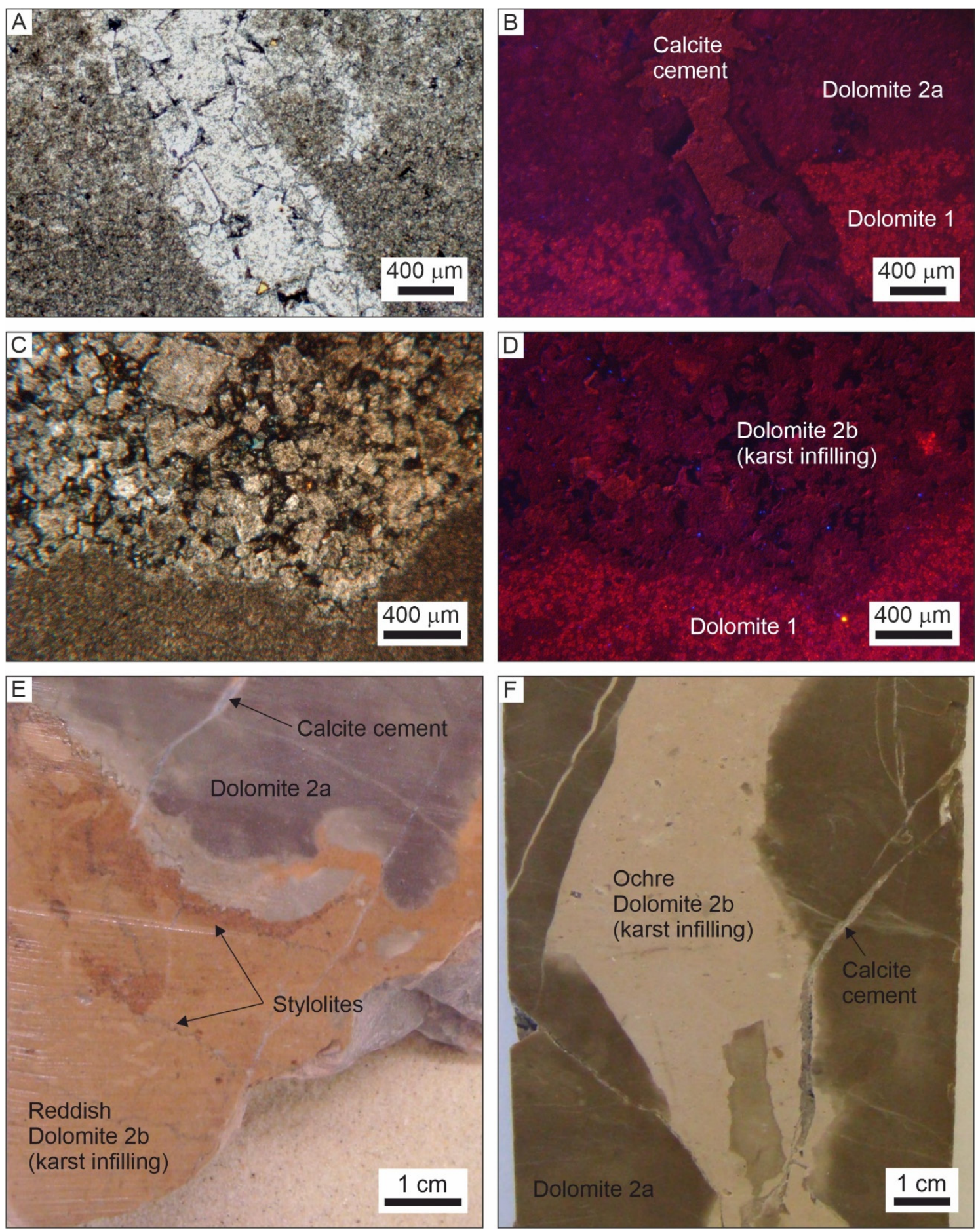

Figure 3. Optical and cathodoluminescence microscope (CL) and hand sample photographs from [15] showing the main features of Dolomite 1, 2a and 2b in Casablanca-1A well. (A,B) CL photomicrographs showing the contact between Dolomite 1 and 2a that are cut by younger calcite cement filling fractures. (C,D) CL photomicrographs showing Dolomite $2 b$ karst fill in a vug developed in Dolomite 1. (E) Polished slab showing reddish Dolomite 2b postdating Dolomite 2a. (F) Polished slab showing ochre Dolomite $2 b$ filling fracture porosity within Dolomite $2 a$. 


\section{Casablanca $\mathrm{C} 1$ well}
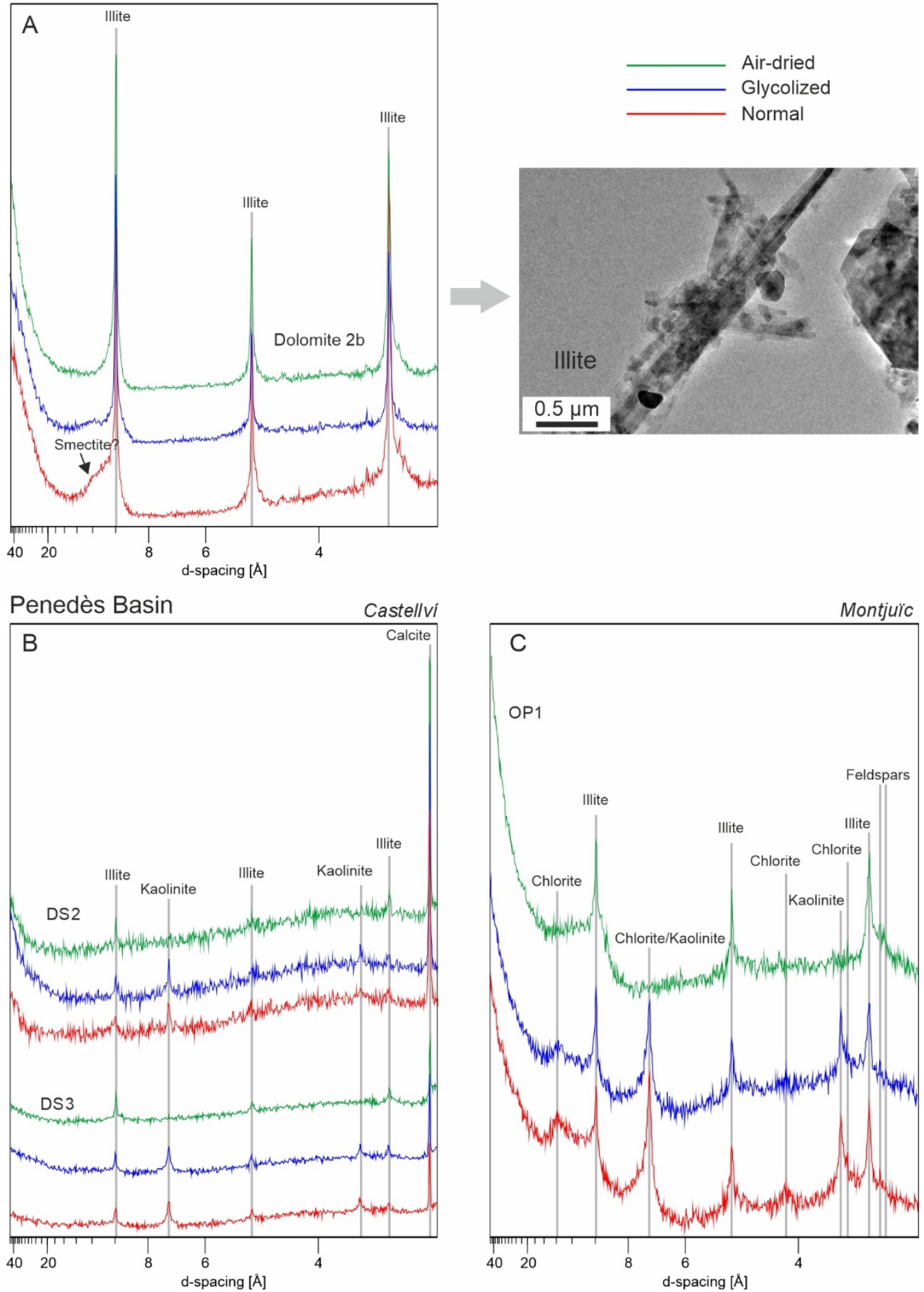

Figure 4. Air-dried, ETG and heated $\left(550{ }^{\circ} \mathrm{C}\right) \mathrm{XRD}$ diagrams of the non-carbonate fraction of Dolomite $2 \mathrm{~b}$ fills in the Casablanca-1A well, DS2 and DS3 dolomite fills in Castellví outcrop and orange pisoids in the Montjuïc outcrop. For Dolomite 2a, XRD spectra are redrawn from [15]. 

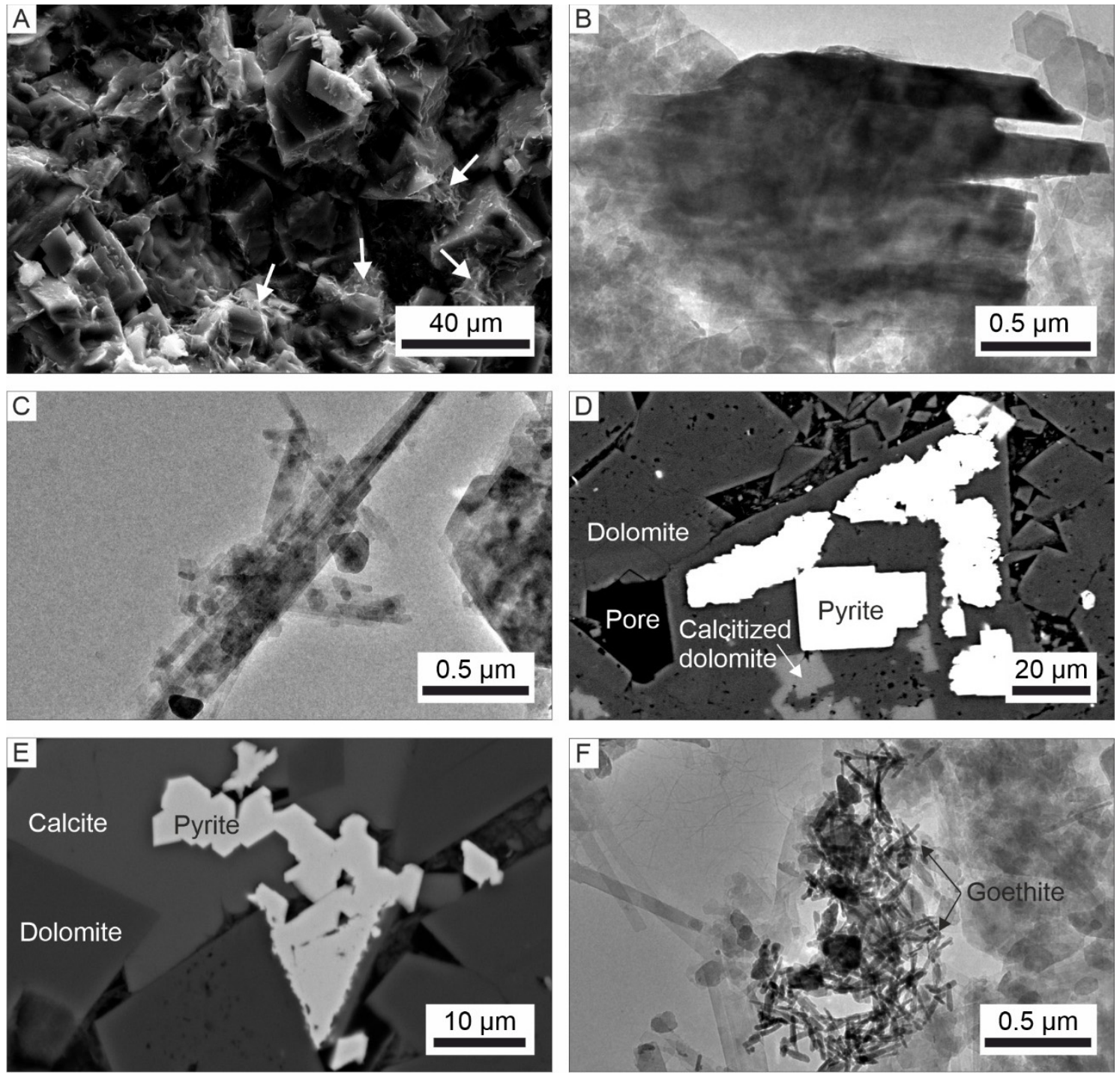

Figure 5. SEM and TEM images of the non-carbonate fraction of Dolomite 2a and 2b in the Casablanca-1A well. (A) SEM microphotograph of Dolomite $2 \mathrm{~b}$ coated by flaky particles of illite (white arrows). (B) TEM microphotograph of an irregular flaky particle of illite. (C) TEM microphotograph of lath-shaped crystals of illite in Dolomite 2B. (D) SEM microphotograph of pyrite placed within growth cavities of dolomite. (E) SEM microphotograph of pyrite disseminated between dolomite crystals. (F) TEM microphotograph of goethite crystals within reddish Dolomite $2 \mathrm{~b}$.

In the Amposta Marino $\mathrm{C} 2$ well, the aforementioned type $\mathrm{C}$ fractures display sharp and undulating walls, locally enlarged by dissolution, and are totally or partially filled by calcite fills and younger calcite cement (Figure 6A). The calcite fill is constituted of reddish (CS3r; Figure 6A) and greenish (CS3g; Figure 6B) microsparite and clay minerals. Calcite fills and cements locally display geopetal structures, with the cement occluding the upper part of fracture porosity (Figure 6C). Individual calcite crystals range in size between 8 and $40 \mu \mathrm{m}$ (Figure $6 \mathrm{C}, \mathrm{D}$ ) and show dull orange to bright orange luminescence (Figure $6 \mathrm{E}, \mathrm{F}$ ). 

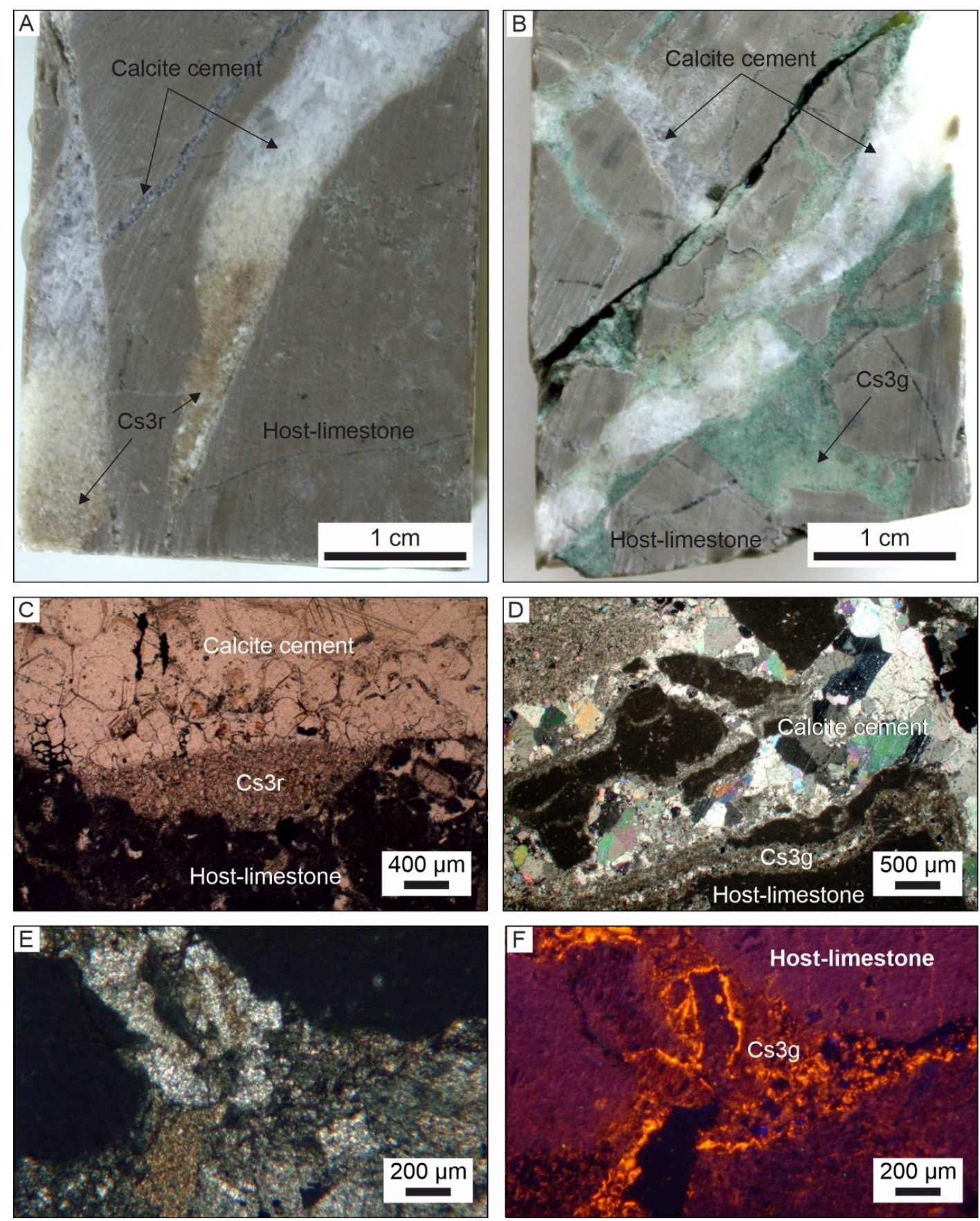

Figure 6. The main features of host limestones and reddish CS3r and greenish CS3g karst fills in the Amposta Marino C2 well (A to D photographs are from [16]). (A) Hand sample of CS3r filling fracture porosity within Lower Cretaceous limestones. (B) Hand sample with CS3g filling fracture porosity. (C) Photomicrograph of geopetal structure filled with CS3r and younger calcite cement (plane polarised light). (D) Photomicrograph of a brecciated host-limestone partially cemented by CS3g and calcite cement (cross polarised light). (E,F) Plane polarised light and cathodoluminescence (CL) images with CS3g filling fracture porosity in Lower Cretaceous limestones.

\subsection{Penedès Basin}

The complete fracture and diagenetic history of the Penedès Basin during the Mesozoic extension, Palaeogene compression and Neogene extension periods were defined by $[3,17,18]$. However, this study focuses on those Neogene karst fills that were identified in the Castellví, Olèrdola and Montjuïc outcrops.

In the Castellví outcrop, there are three different karst fills: dolomite DS2 and DS3 and calcite CS1. Dolomite fills are found in randomly oriented fractures affected by strong 
dissolution. Specifically, DS2 fills channel and vug porosities generated by this process, and DS3 is observed in a rubble floatbreccia produced by fracture wall collapse. Dolomite DS2 is red to orange in colour (Figure 7A,B) and consists of micro-fragments of the host dolostone RD1. This non-luminescent to orange luminescent fill is cemented by dolomite (Figure 7C,D), which is arranged in a rim position at the walls of the fracture or surrounding the host dolomite fragments. The non-carbonate fraction of DS2 is constituted of illite, kaolinite and quartz (Figure 4B). Dolomite DS3 is a pink to red laminated fill (Figure 7A,B) and consists of bright orange luminescent euhedral dolomite crystals (Figure 7C,D). This fill contains abundant iron oxides, which are not detected by XRD. However, as with DS2, the spectra of the non-carbonate fraction of DS3 reveal the presence of illite, kaolinite and quartz (Figure 4B). Pink and laminated calcite CS1 surrounds calcite cement precipitated between spelean pisoids, which form layers parallel to the main normal fault (Figure 7E). This fill consists of non-luminescent blocky anhedral calcite crystals, 4-10 $\mu \mathrm{m}$ in size (Figure 7F).
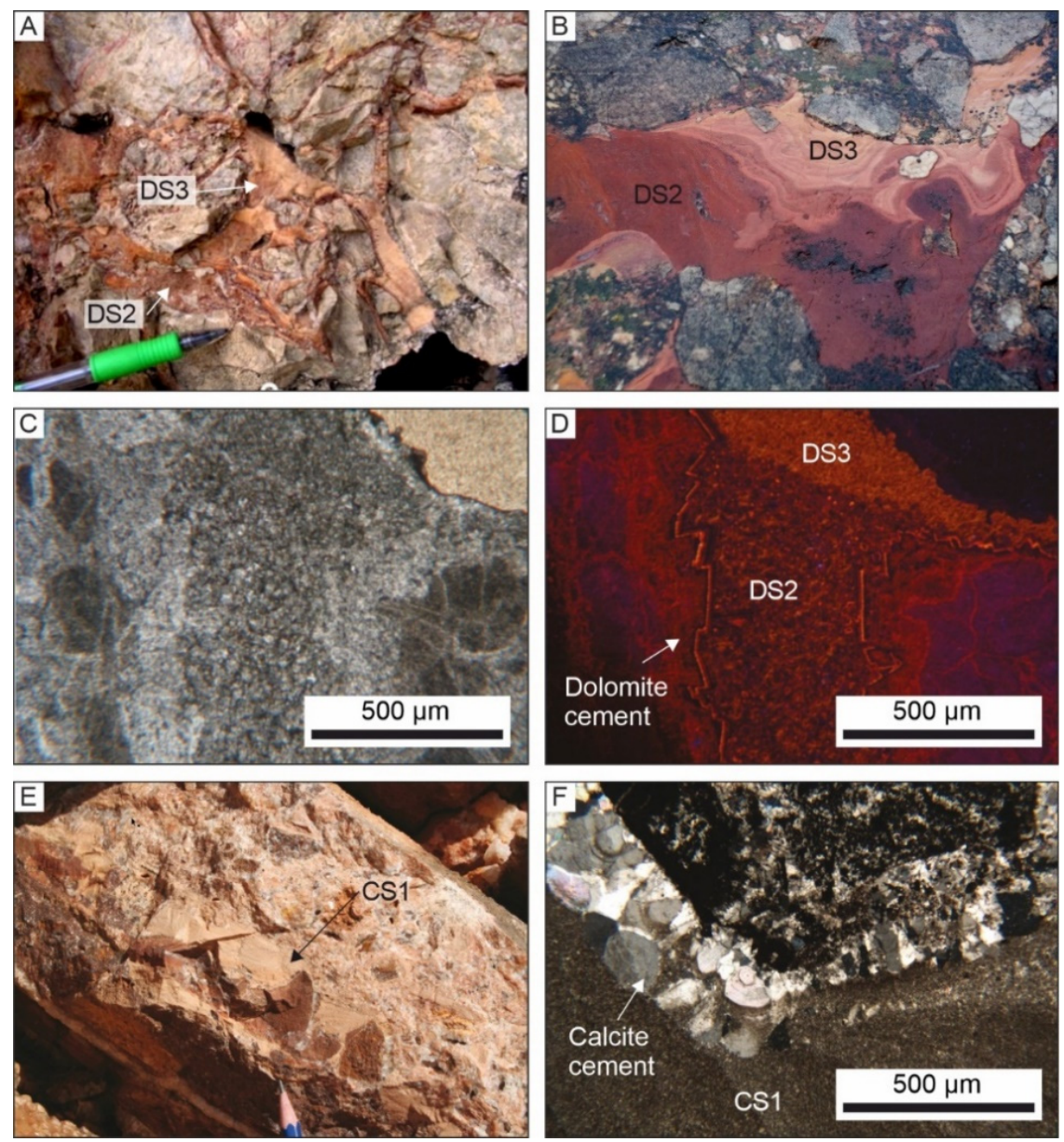

Figure 7. Main features of host dolostones RD1 and DS2, DS3 and CS1 karst fill in the Castellví outcrop (C,D photographs are from [3]). (A) Field photograph of DS2 and DS3 within fractures in RD1. (B) Field photograph of DS2 and DS3 filling a karst cavity within RD1. (C,D) Optical (plane polarised light) and CL images of the relationships between DS2, DS3 and dolomite cement. (E) Field photograph of CS1 bounding fragments of RD1. (F) Photomicrograph of CS1 bounded by calcite cement in contact with RD1 fragment (cross polarised light).

The host rocks of the Olèrdola and Montjuïc outcrops are Lower Cretaceous limestones. Two types of karst fills are present in fractures of the Olèrdola outcrop. The first fill consists of orange calcite CS2 (Figure 8A,B), constituted by subhedral microsparite crystals showing zoned red to orange luminescence (Figure $8 \mathrm{C}, \mathrm{D}$ ). Calcite cement associated with CS2 is 
constituted by non-luminescent to orange luminescent zoned euhedral crystals arranged in a rim position at the fracture walls. The second fill is a locally laminated red calcite CS3 constituted by bright red to orange luminescent micrite and abundant iron oxides (Figure 8A-D).
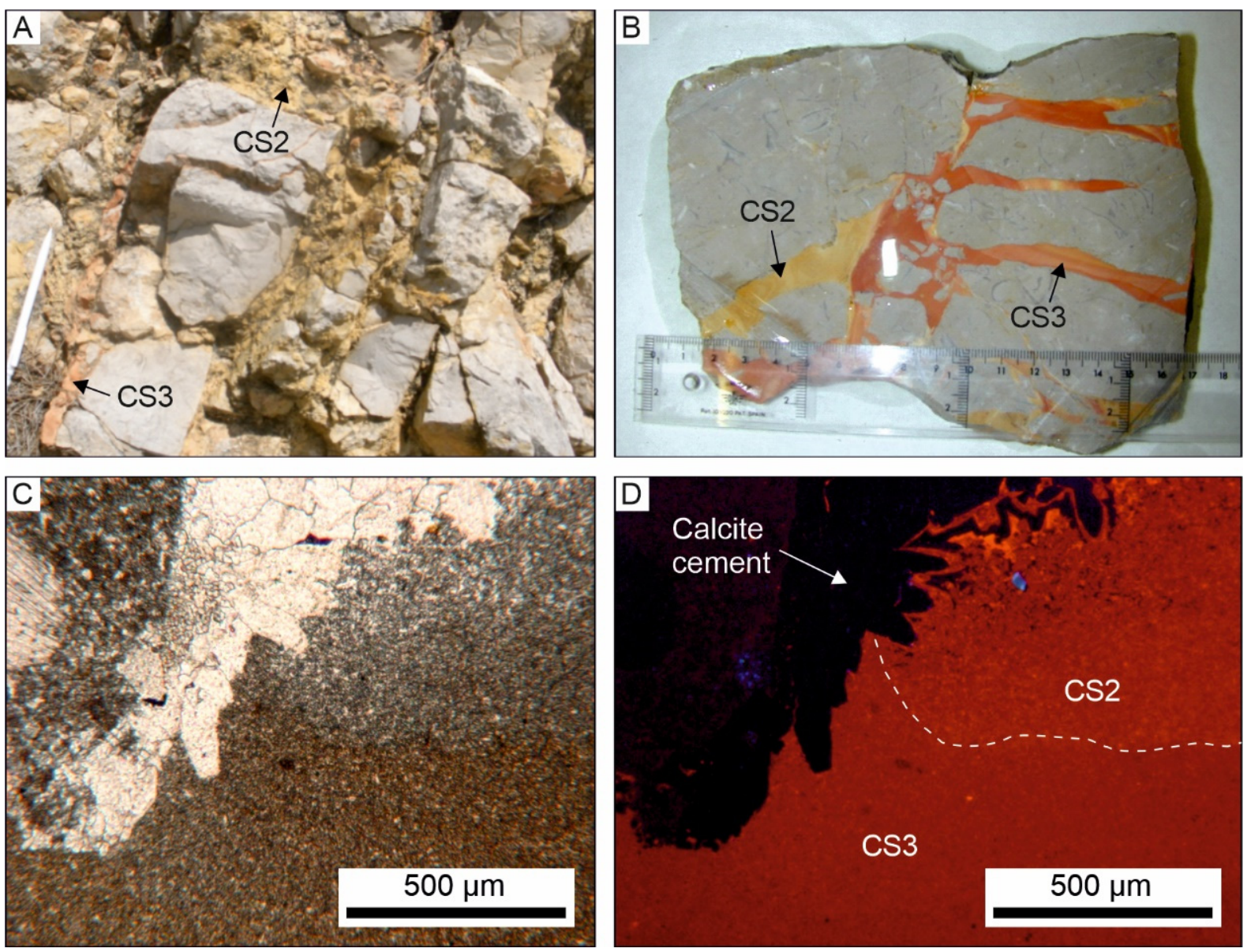

Figure 8. Main features of Lower Cretaceous host limestones, CS2 and CS3 karst fills in the Olèrdola outcrop. (A,B) Field photograph of CS2 and CS3 within fractures in Lower Cretaceous limestones. (C,D) Optical (plane polarised light) and cathodoluminescence image of the relationships between CS2, CS3 and calcite cement. Note the microsparite and micrite textures of CS2 and CS3, respectively.

Lower Cretaceous limestones from the footwall of a normal fault are in contact with Neogene siliciclastic sediments of the hangingwall at the Montjuïc outcrop. The fault zone consists of a cataclasite (Figure 9A), which is surrounded by fractures filled with collapse-breccias with an orange fill made of pisoids (OP1) (Figure 9B). Breccia fragments are derived from adjacent host rocks and are supported by the orange fill, which displays red luminescence (Figure 9C,D). The non-carbonate fraction of OP1 consists of chlorite, kaolinite, illite and feldspars (Figure 4C). 

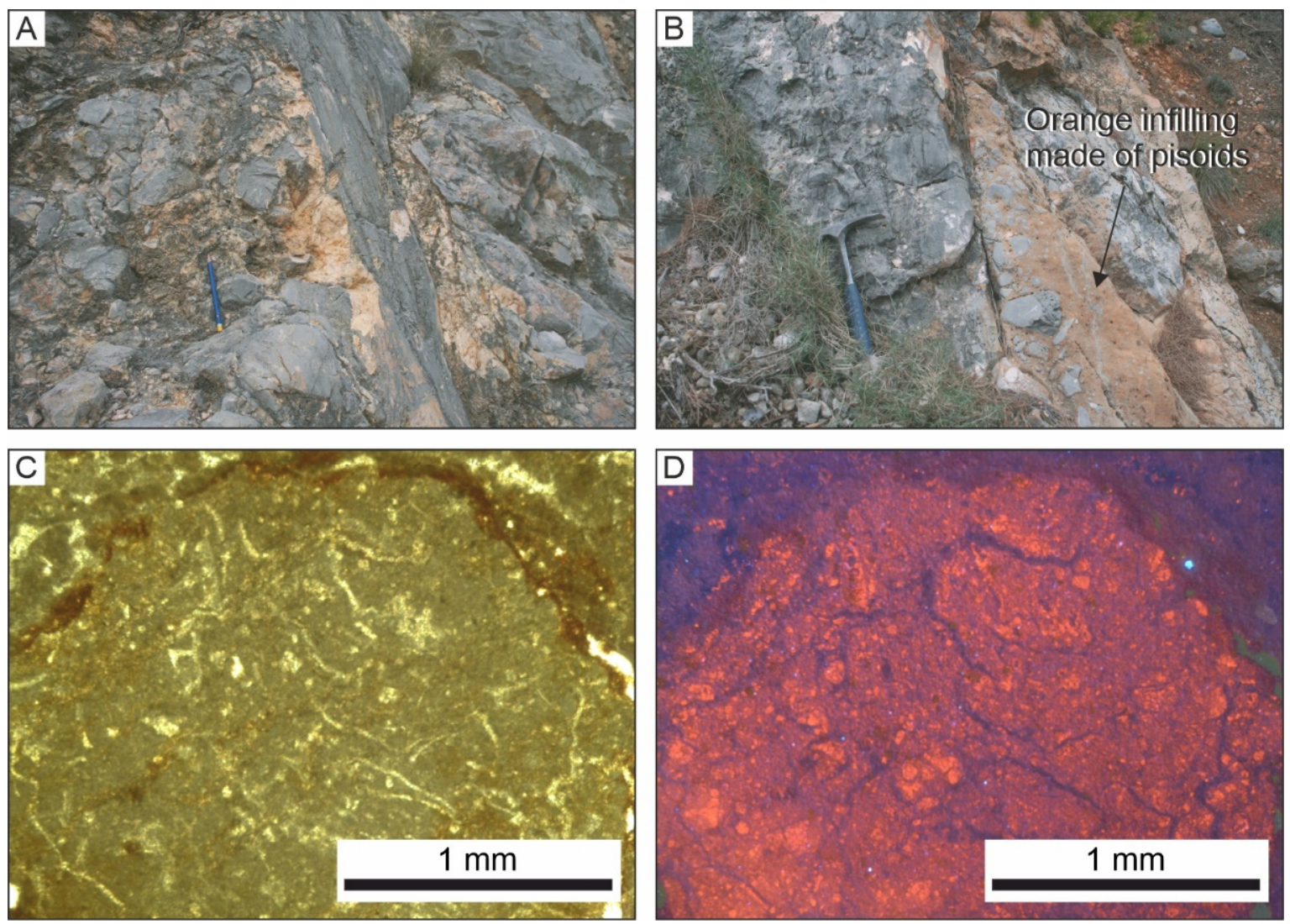

Figure 9. (A) Neogene normal fault plane showing a cataclasite formed during the movement of the fault. (B) Fractures filled with collapse-breccias and the orange fill made of pisoids (OP1). (C,D) Optical (plane polarised light) and cathodoluminescence images of OP1 fill.

\section{Geochemistry of the Karst Fills and Host Rocks}

The Mesozoic carbonate host rocks and Neogene karst fills of the offshore Casablanca and Amposta oil fields, as well as of the onshore Penedès Basin, were studied in terms of their oxidation state and their elemental and isotopic composition. Analyses were carried out using Mössbauer spectrometry, electron microprobe and $\delta^{18} \mathrm{O}, \delta^{13} \mathrm{C}$ and ${ }^{87} \mathrm{Sr} /{ }^{86} \mathrm{Sr}$ isotope analysis.

\subsection{Fe Oxidation State (Mössbauer Spectrometry)}

The Mössbauer spectra of carbonate host rocks and karst fills of the offshore Casablanca1A well and onshore Penedès Basin are shown in Figure 10, and the results are listed in Table 3.

\subsubsection{Casablanca-1A Well}

Mössbauer spectra of the host Dolomite 2a in contact with Dolomite 2b show two doublets partially overlapped. Those doublets with higher values of isomer shift and quadrupolar splitting $\left(\delta_{\mathrm{Fe}}=1.24 \mathrm{~mm} / \mathrm{s}, \Delta=1.45 \mathrm{~mm} / \mathrm{s}\right.$ and $\delta_{\mathrm{Fe}}=1.17 \mathrm{~mm} / \mathrm{s}, \Delta=1.58 \mathrm{~mm} / \mathrm{s}$, respectively), are attributed to high spin $\mathrm{Fe}^{2+}$, whereas the doublets with lower values $\left(\delta_{\mathrm{Fe}}=0.21 \mathrm{~mm} / \mathrm{s}, \Delta=0.36 \mathrm{~mm} / \mathrm{s}\right.$ and $\left.\delta_{\mathrm{Fe}}=0.31 \mathrm{~mm} / \mathrm{s}, \Delta=0.46 \mathrm{~mm} / \mathrm{s}\right)$ arise from the presence of $\mathrm{Fe}^{3+}$. With respect to the relative content in $\mathrm{Fe}$ species, although $\mathrm{Fe}^{2+}$ is the dominant species in both cases, the $\mathrm{Fe}^{2+} / \mathrm{Fe}^{3+}$ ratio is 4.3 for Dolomite 2a in the host rock in contact with the reddish Dolomite $2 \mathrm{~b}$ and 1.9 for Dolomite $2 \mathrm{a}$ in contact with ochre Dolomite $2 \mathrm{~b}$. 


\section{Casablanca-1A well}
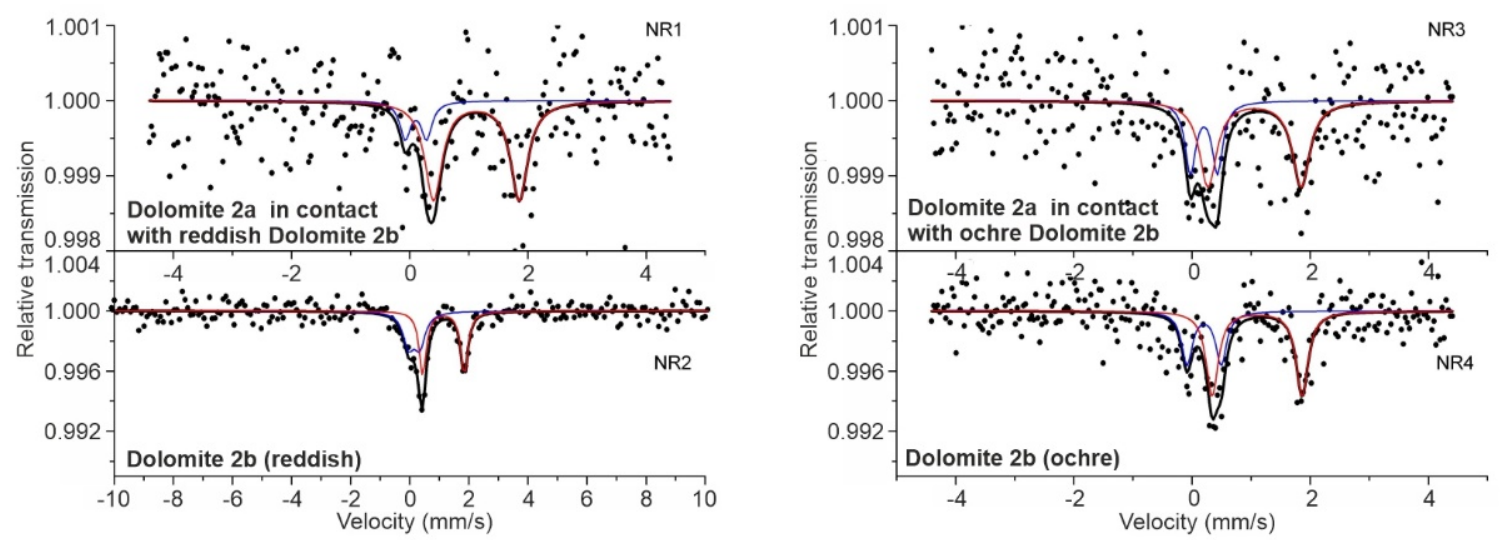

\section{Penedès Basin}
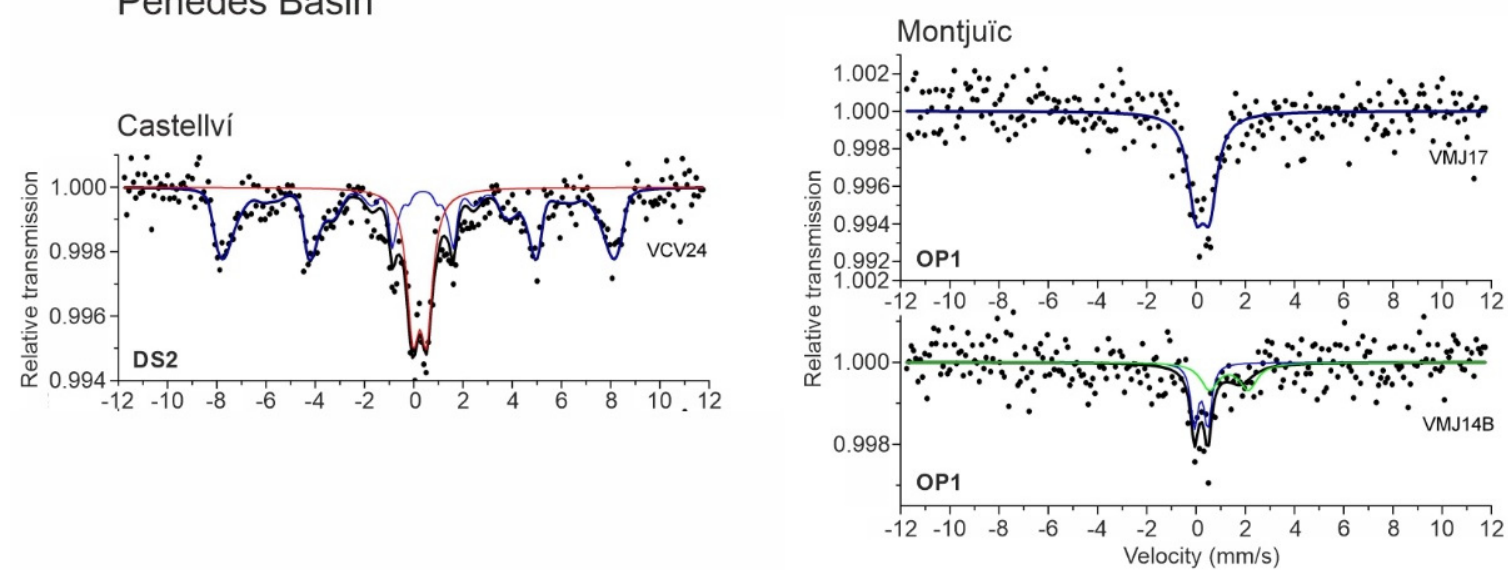

Figure 10. Mössbauer spectra of Dolomite 2a (in contact with red or ochre Dolomite $2 b$ ) and Dolomite $2 b$ in the Casablanca 1A oil well, as well as dolomite DS2 in Castellví outcrop and the orange fill made of pisoids in Montjuïc outcrop from the Penedès Basin (OP1).

Table 3. Hyperfine parameters of Mössbauer spectra. $\Gamma(\mathrm{mm} / \mathrm{s})$ : full width at half maximum peak; $\delta_{\mathrm{Fe}}(\mathrm{mm} / \mathrm{s}):$ isomer shift; $\Delta(\mathrm{mm} / \mathrm{s})$ : quadrupolar splitting; $2 \varepsilon(\mathrm{mm} / \mathrm{s})$ quadrupolar shift; $\mathrm{B}_{\mathrm{hf}}(\mathrm{T})$ : hyperfine field.

\begin{tabular}{|c|c|c|c|c|c|c|c|c|c|}
\hline Sample & Description/Colour & $\Gamma(\mathrm{mm} / \mathrm{s})$ & $\begin{array}{c}\mathcal{\delta}_{\mathrm{Fe}} \\
(\mathrm{mm} / \mathrm{s})\end{array}$ & $\Delta(\mathrm{mm} / \mathrm{s})$ & $\begin{array}{c}2 \varepsilon \\
(\mathrm{mm} / \mathrm{s})\end{array}$ & $\mathbf{B}_{\mathrm{hf}}$ & $\%$ & Interpretation & $\begin{array}{c}\mathrm{Fe}^{2+} / \mathrm{Fe}^{3+} \\
\text { Ratio }\end{array}$ \\
\hline \multicolumn{10}{|c|}{$\begin{array}{l}\text { Casablanca-1A } \\
\text { well }\end{array}$} \\
\hline NR1 & $\begin{array}{c}\text { Dolomite 2a } \\
\text { (host rock) }\end{array}$ & $\begin{array}{l}0.22(-) \\
0.35(-)\end{array}$ & $\begin{array}{l}0.21(4) \\
1.24(2)\end{array}$ & $\begin{array}{l}0.36(7) \\
1.45(4)\end{array}$ & & - & $\begin{array}{l}19 \\
81\end{array}$ & $\begin{array}{l}\mathrm{Fe}^{3+} \\
\mathrm{Fe}^{2+}\end{array}$ & 4.3 \\
\hline NR2 & $\begin{array}{c}\text { Reddish Dolomite } 2 \mathrm{~b} \\
\text { (karst fill) }\end{array}$ & $\begin{array}{l}0.44(6) \\
0.29(3)\end{array}$ & $\begin{array}{l}0.26(3) \\
1.25(1)\end{array}$ & $\begin{array}{l}0.38(4) \\
1.41(2)\end{array}$ & & - & $\begin{array}{l}01 \\
43.5 \\
56.5\end{array}$ & $\begin{array}{l}\mathrm{Fe}^{3+} \\
\mathrm{Fe}^{2+}\end{array}$ & 1.3 \\
\hline NR3 & $\begin{array}{l}\text { Dolomite2a } \\
\text { (host rock) }\end{array}$ & $\begin{array}{l}0.22(-) \\
0.35(-)\end{array}$ & $\begin{array}{l}0.31(2) \\
1.17(2)\end{array}$ & $\begin{array}{l}0.46(4) \\
1.58(4)\end{array}$ & & - & $\begin{array}{l}34 \\
66\end{array}$ & $\begin{array}{l}\mathrm{Fe}^{3+} \\
\mathrm{Fe}^{2+}\end{array}$ & 1.9 \\
\hline NR4 & $\begin{array}{l}\text { Ochre Dolomite } 2 \mathrm{~b} \\
\quad \text { (karst fill) }\end{array}$ & $\begin{array}{l}0.22(2) \\
0.25(2)\end{array}$ & $\begin{array}{l}0.31(1) \\
1.21(1)\end{array}$ & $\begin{array}{l}0.58(2) \\
1.52(2)\end{array}$ & & $\begin{array}{l}- \\
-\end{array}$ & $\begin{array}{l}36 \\
64\end{array}$ & $\begin{array}{l}\text { Pyrite } \\
\mathrm{Fe}^{2+}\end{array}$ & - \\
\hline \multicolumn{10}{|c|}{$\begin{array}{l}\text { Penedès Basin } \\
\text { Castellví }\end{array}$} \\
\hline VCV24 & $\begin{array}{c}\text { DS2 } \\
\text { (karst fill) }\end{array}$ & $\begin{array}{c}0.60(5) \\
-\end{array}$ & $\begin{array}{l}0.35(2) \\
0.39(2)\end{array}$ & $0.55(3)$ & $-0.19(3)$ & $\begin{array}{c}- \\
\text { DIST }\end{array}$ & $\begin{array}{l}34 \\
66\end{array}$ & $\begin{array}{c}\text { Pyrite? } \\
\text { Hematite/Goethite. }\end{array}$ & - \\
\hline $\begin{array}{c}\text { Montjuïc } \\
\text { VMJ17 } \\
\text { VMJ14B }\end{array}$ & $\begin{array}{l}\text { OP1 } \\
\text { OP1 }\end{array}$ & $\begin{array}{l}0.22(8) \\
0.36(6) \\
1.26(6)\end{array}$ & $\begin{array}{l}0.38(2) \\
0.32(2) \\
1.13(2)\end{array}$ & $\begin{array}{l}0.55(3) \\
0.54(4) \\
1.59(3)\end{array}$ & & $\begin{array}{l}- \\
- \\
-\end{array}$ & $\begin{array}{c}100 \\
49 \\
51\end{array}$ & $\begin{array}{c}\text { Pyrite? } \\
\text { Pyrite? } \\
\mathrm{Fe}^{2+}\end{array}$ & - \\
\hline
\end{tabular}


Mössbauer spectra for reddish Dolomite $2 b$ have two doublets partially overprinted (Table 3). Again, the doublet with higher values of isomer shift and quadrupolar splitting $\left(\delta_{\mathrm{Fe}}=1.25 \mathrm{~mm} / \mathrm{s}, \Delta=1.41 \mathrm{~mm} / \mathrm{s}\right)$, is attributed to high spin $\mathrm{Fe}^{2+}$, whereas the doublet with minor quadrupolar splitting $\left(\delta_{\mathrm{Fe}}=0.26 \mathrm{~mm} / \mathrm{s}, \Delta=0.38 \mathrm{~mm} / \mathrm{s}\right)$ is attributed to $\mathrm{Fe}^{3+}$. With respect to the relative content in Fe species, for this karst fill, $\mathrm{Fe}^{2+}$ is still dominant, but the $\mathrm{Fe}^{2+} / \mathrm{Fe}^{3+}$ ratio is very low, with a value of 1.3.

Mössbauer spectra for ochre Dolomite $2 \mathrm{~b}$ also show two doublets partially overlapped (Table 3). The first doublet, with higher quadrupolar splitting $\left(\delta_{\mathrm{Fe}}=1.21 \mathrm{~mm} / \mathrm{s}\right.$, $\Delta=1.51 \mathrm{~mm} / \mathrm{s})$, is attributed to undetermined $\mathrm{Fe}^{2+}$. Despite having values within the known range of $\mathrm{Fe}^{3+}$, the hyperfine parameters of the second doublet match very well with low spin $\mathrm{Fe}^{2+}$ of pyrite. Therefore, iron from ochre Dolomite $2 \mathrm{~b}$ would be mostly present as $\mathrm{Fe}^{2+}$.

\subsubsection{Penedès Basin}

The orange-reddish fills of the Castellví and Montjuïc outcrops from the onshore Penedès Basin were analysed. The results of the Mössbauer spectra are less clear than those in the offshore Casablanca oil field.

At the Castellví outcrop, only the Mössbauer spectrum for the orange-reddish in DS2 fills was measured. The corresponding spectrum contains a doublet and a distribution of magnetic sextets (Table 3). The doublet $\left(\delta_{\mathrm{Fe}}=0.35 \mathrm{~mm} / \mathrm{s}, \Delta=0.55 \mathrm{~mm} / \mathrm{s}\right)$ could be attributed to pyrite as in ochre Dolomite $2 \mathrm{~b}$ (Casablanca-1A well), but the quadrupolar is slightly too small so it could be interpreted as $\mathrm{Fe}^{3+}$. The magnetic sextet contains two separate distributions (DIST) of hyperfine fields on the one hand, from 19 to $27 \mathrm{~T}$, with a maximum at $21.6 \mathrm{~T}$ and on the other hand from 33 to $53 \mathrm{~T}$, with two maxima at $28 \mathrm{~T}$ and 49.6 T. Considering the negative value of quadrupolar shift $(\Delta=-0.19 \mathrm{~mm} / \mathrm{s})$, this wide and complex distribution can be interpreted as the size distribution of microcrystalline hematite including nanosized particles. A contribution of goethite to the observed hyperfine field distribution cannot be excluded.

Two samples of OP1from the Montjuïc outcrop were analysed. One of them has a single peak $\left(\delta_{\mathrm{Fe}}=0.38 \mathrm{~mm} / \mathrm{s}, \Delta=0.55 \mathrm{~mm} / \mathrm{s}\right)$, which again could be interpreted either as pyrite, although its quadrupolar is slightly too small, or simply $\mathrm{Fe}^{3+}$. The other sample, although macroscopically similar to the previous one, shows two doublets partially overlapped (Table 3 ). The one with the smaller hyperfine parameters $\left(\delta_{\mathrm{Fe}}=0.32 \mathrm{~mm} / \mathrm{s}, \Delta=0.54 \mathrm{~mm} / \mathrm{s}\right)$ would be again pyrite or simply $\mathrm{Fe}^{3+}$, whereas the widest $\left(\delta_{\mathrm{Fe}}=1.13 \mathrm{~mm} / \mathrm{s}, \Delta=1.59 \mathrm{~mm} / \mathrm{s}\right)$ is attributed to $\mathrm{Fe}^{2+}$.

\subsection{Minor and Trace Elements Content}

The Mg, Mn, Fe and Sr content of the carbonate host-rocks and karst fills of the offshore Casablanca C1 and Amposta Marino C2 oil wells, as well as of the Castellví, Olèrdola and Montjuïc outcrops of the onshore Penedès Basin, are summarised in Figure 11 and Table S1.

\subsubsection{Casablanca-1A Well}

Dolomite 1 has Mg contents between 122,215 and 118,742 ppm, Fe content between 2514 and $2950 \mathrm{ppm}$ and $\mathrm{Sr}$ content between 397 and $479 \mathrm{ppm}$. The Mn content is below the detection limit. Dolomite 2a has Mg content between 128,604 and 118,800 ppm, Fe content from below the detection limit up to $8341 \mathrm{ppm}$ and Sr content from below the detection limit to $677 \mathrm{ppm}$. The Mn content is below the detection limit. Dolomite $2 \mathrm{~b}$ replacing the ochre fills has Mg content between 122,661 and 122,545 ppm, Fe content between 1959 and $7051 \mathrm{ppm}$, Sr content from below the detection limit to $672 \mathrm{ppm}$ and Mn content below the detection limit. 

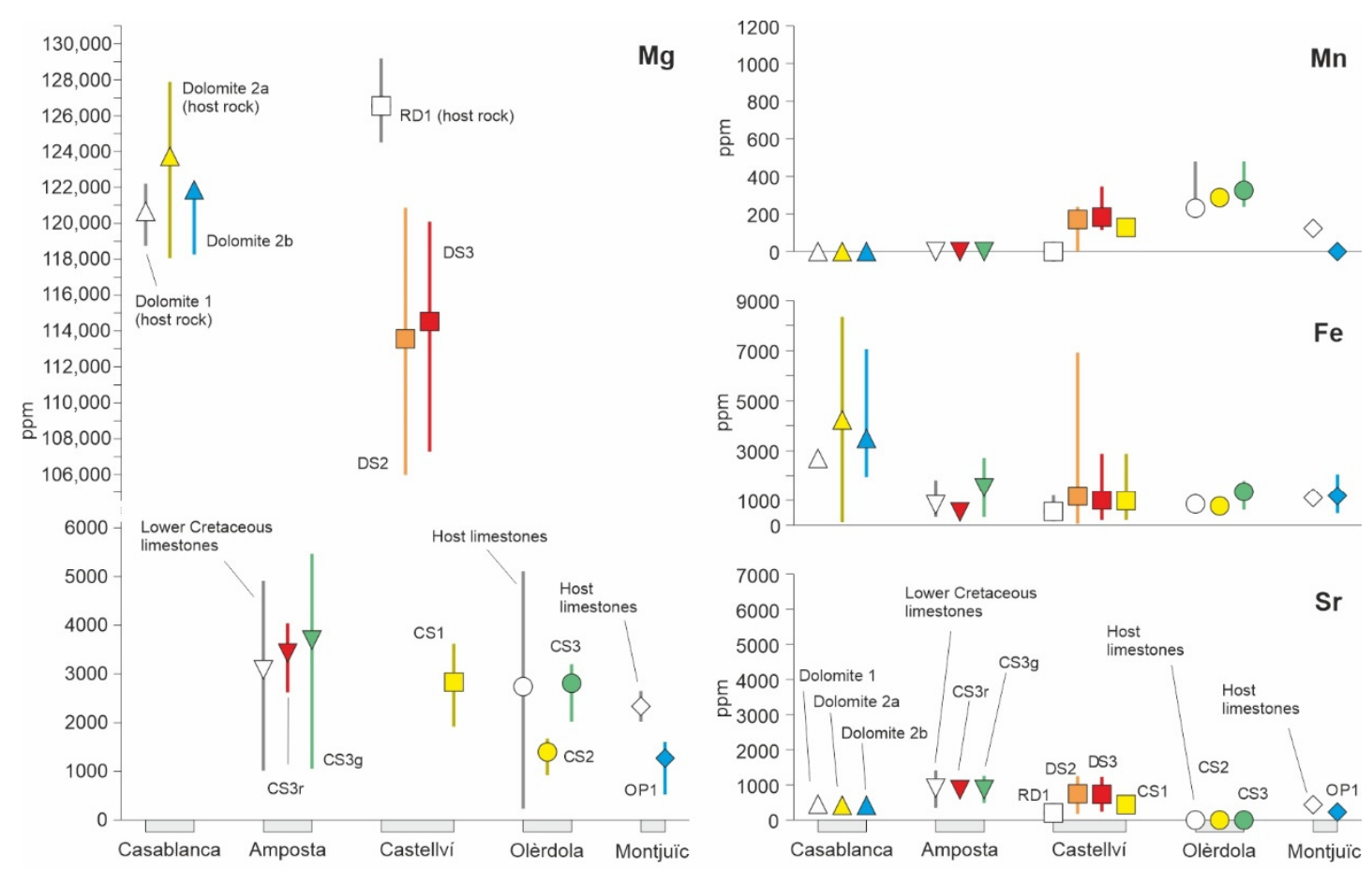

Figure 11. Maximum, minimum and mean $\mathrm{Mg}, \mathrm{Mn}, \mathrm{Fe}$ and $\mathrm{Sr}$ contents in ppm of the karst fills and host carbonates in the Casablanca and Amposta oil wells and in the Penedès Basin.

\subsubsection{Amposta Marino C2 Well}

Lower Cretaceous host-limestones have Mg and Sr contents from 1013 to 4909 ppm and between 355 and 1407 ppm, respectively. Their Mn contents are below the detection limit. The Fe content displays values from below the detection limit to $1813 \mathrm{ppm}$. The reddish calcite CS3r fill has $\mathrm{Mg}$ and Sr contents ranging from 2619 to $4038 \mathrm{ppm}$ and 640 to 1053 ppm, respectively. Its Fe content range from below the detection limit and 721 ppm, whereas the Mn content is below the detection limit. The Mg and $\mathrm{Sr}$ contents of the greenish calcite CS3g fill vary from 1052 to 5461 ppm and from 491 to 1259 ppm, respectively. Its Fe content range from below the detection limit and $2701 \mathrm{ppm}$, whereas $\mathrm{Mn}$ is below the detection limit.

\subsubsection{Penedès Basin}

Karst fills and host rocks of the Penedès Basin have higher Mn contents than those of the Casablanca-1A and Amposta Marino-C2 oil wells. The Mg, Fe and Sr contents do not show a clear trend. The elemental composition of replacive dolomite RD1 and DS2, DS3 and CS1 karst fills was measured in samples from the Castellví outcrop. For RD1, Mg ranges between 130,202 and 125,280 ppm and between 129 and 316 ppm in Sr. Its Fe content ranges from below the detection limit to $1181 \mathrm{ppm}$. The Mn content is below the detection limit. For DS2, the Mg content ranges from 120,843 to 105,966 ppm, and the Mn content ranges from below the detection limit and 235 ppm; the Fe ranges from 52 to 6927 ppm and the Sr content between 177 and 1250 ppm. For DS3, Mg ranges between 120,083 and 107,265, Mn between 115 and 346 ppm, Fe between 213 and 1866 and Sr between 237 and $1228 \mathrm{ppm}$. For CS1, the Mg content is from 1915 to $3620 \mathrm{ppm}$, the Mn content is from below the detection limit to $128 \mathrm{ppm}$, the Fe content is between 212 and $2885 \mathrm{ppm}$ and the Sr ranges from 292 and $686 \mathrm{ppm}$.

The Mg content of host limestones from the Olèrdola outcrop ranges between 231 and 5103 ppm, the Mn content is between 231 and 478 ppm, the Fe content is between 578 and $1253 \mathrm{ppm}$ and the Sr content is below the detection limit. For CS2, the Mg content ranges from 1672 to $923 \mathrm{ppm}$, and the Mn and Fe contents range from 239 to 287 and from 530 to 916 ppm, respectively. The Sr content is below the detection limit. For CS3, the Mg, 
Mn and Fe contents range from 2018 to $3200 \mathrm{ppm}$, from 239 and $478 \mathrm{ppm}$ and from 627 to $1784 \mathrm{ppm}$, respectively. The $\mathrm{Sr}$ content is below the detection limit.

The host limestones from the Montjuïc outcrop have Mg content from 2020 to 2652, Mn content from 108 to $126 \mathrm{ppm}$, Fe content from 1078 to $1127 \mathrm{ppm}$ and Sr content from 430 to $444 \mathrm{ppm}$. OP1 has Mg content from 522 to $1602 \mathrm{ppm}$, Mn content below the detection limit, Fe content from 478 to 2056 ppm and Sr content from 179 to $297 \mathrm{ppm}$.

\section{3. $\delta^{18} \mathrm{O}, \delta^{13} \mathrm{C}$ and ${ }^{87} \mathrm{Sr} /{ }^{86} \mathrm{Sr}$ Isotope Geochemistry}

For the host carbonates and karst fills of the offshore Casablanca-1A and Amposta Marino C2 oil wells, as well as in the Castellví, Olèrdola and Montjuïc outcrops of the onshore Penedès Basin, their $\delta^{18} \mathrm{O}$ and $\delta^{13} \mathrm{C}$ are plotted in Figure 12 and summarised in Table S2. The ${ }^{87} \mathrm{Sr} /{ }^{86} \mathrm{Sr}$ isotopic ratios are plotted in Figure 13 and summarised in Table S3.

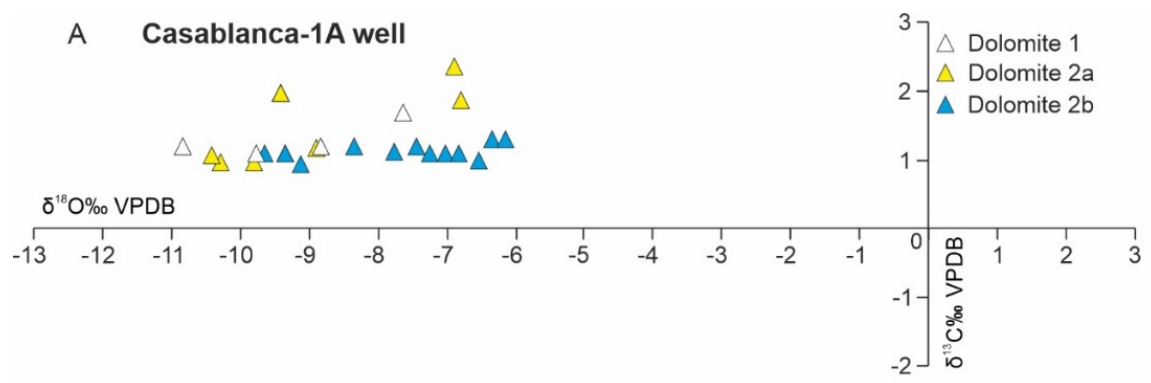

B Amposta Marino C2 well
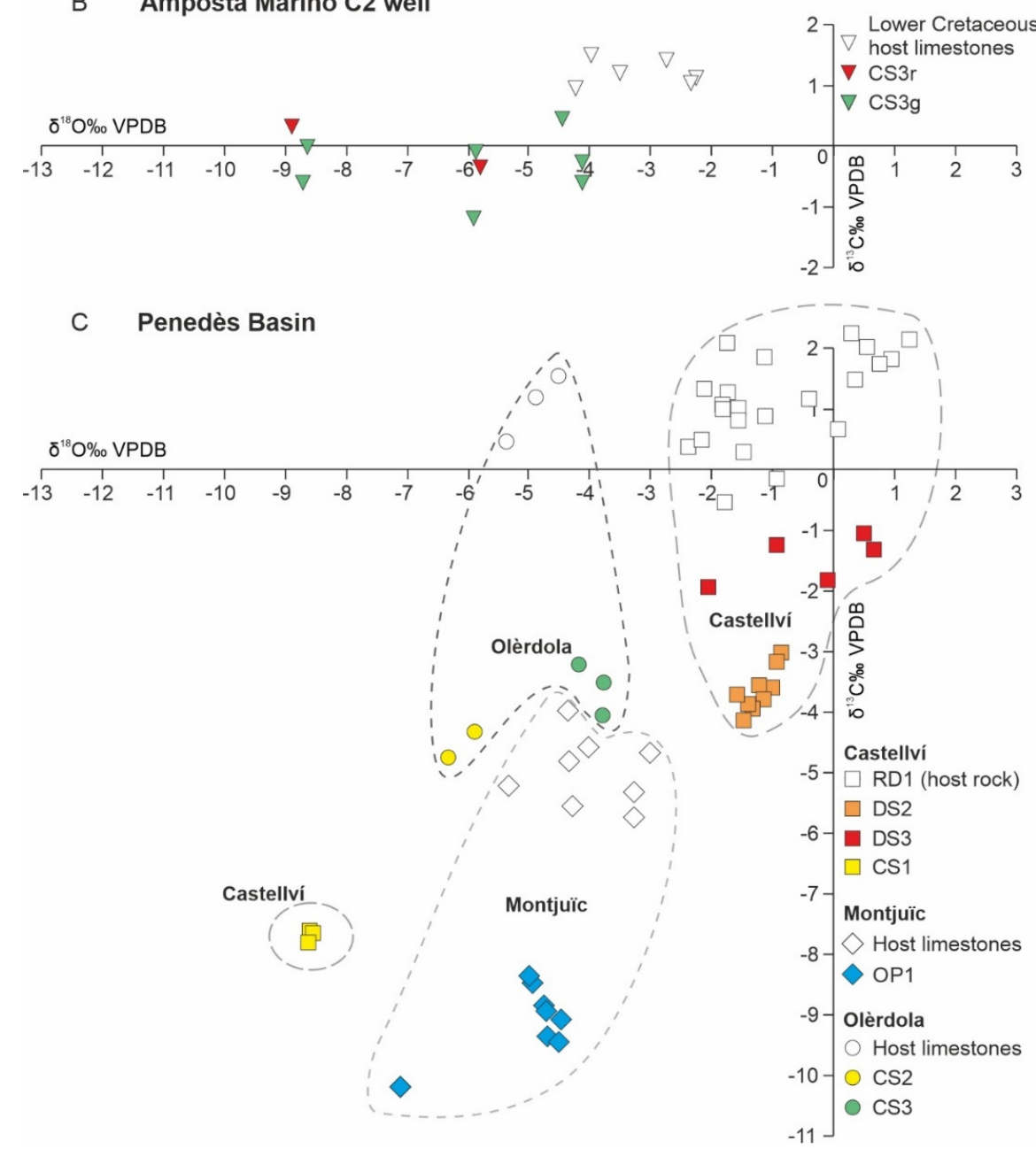

Figure 12. $\delta^{18} \mathrm{O}$ vs. $\delta^{13} \mathrm{C}$ of the karst fills and host carbonates in the Casablanca and Amposta oil wells and in the Penedès Basin. 


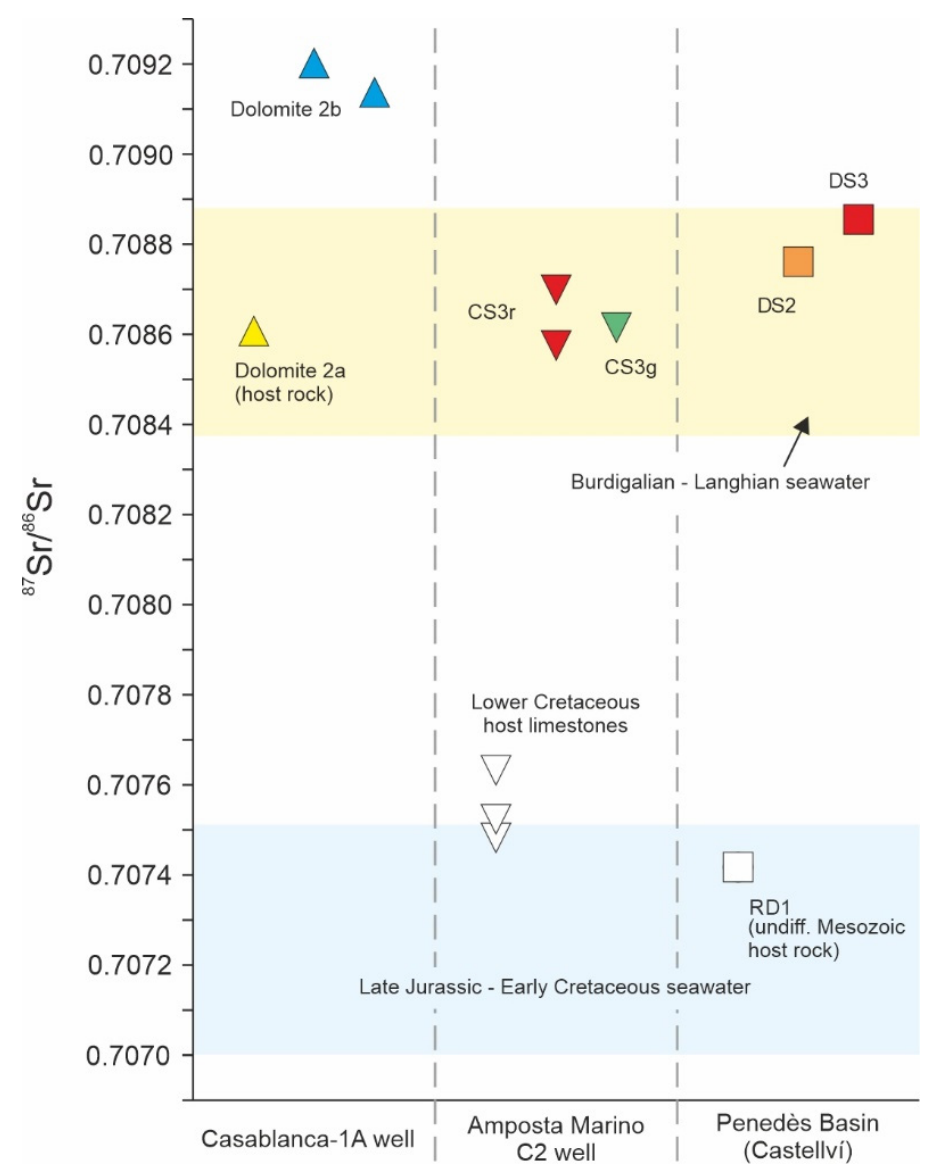

Figure 13. The ${ }^{87} \mathrm{Sr} /{ }^{86} \mathrm{Sr}$ ratios of the karst fills and host carbonates in the Casablanca and Amposta oil wells as well as in the Castellví outcrop in the Penedès Basin compared with values of Late JurassicEarly Cretaceous and Burdigalian-Langhian seawater. Seawater ratios are from the LOWESS curve of [40].

\subsubsection{Casablanca-1A Well}

Dolomite 1 has $\delta^{18} \mathrm{O}$ ranging between -10.8 and $-7.6 \%$ VPDB, and $\delta^{13} \mathrm{C}$ between +1.1 and $+1.7 \%$ VPDB. Dolomite $2 \mathrm{a}$ has $\delta^{18} \mathrm{O}$ ranging between -10.4 and $-6.8 \%$ VPDB, $\delta^{13} \mathrm{C}$ between +1.0 and $+2.4 \%$ VPDB and an ${ }^{87} \mathrm{Sr} /{ }^{86} \mathrm{Sr}$ ratio of 0.708607 . Dolomite $2 \mathrm{~b}$ show $\delta^{18} \mathrm{O}$ values similar to Dolomite 2a, or slightly heavier in the ochre fills, and $\delta^{13} \mathrm{C}$ ranging between +1.0 and $+1.4 \%$ VPDB. The ${ }^{87} \mathrm{Sr} /{ }^{86} \mathrm{Sr}$ ratios for the reddish and ochre fills of dolomite $2 \mathrm{~b}$ are 0.709137 and 0.709202 , respectively.

\subsubsection{Amposta Marino C2 Well}

Lower Cretaceous limestones have $\delta^{18} \mathrm{O}$ values from -4.2 to $-2.2 \%$ VPDB, $\delta^{13} \mathrm{C}$ values between +0.9 and $+1.5 \%$ VPDB and ${ }^{87} \mathrm{Sr} /{ }^{86} \mathrm{Sr}$ ratios ranging from 0.70748 to 0.70763. The $\delta^{18} \mathrm{O}$ and $\delta^{13} \mathrm{C}$ values of CS3r range from -9.9 to $-5.6 \%$ VPDB and from -1.4 to $+0.3 \%$ VPDB, respectively. Its ${ }^{87} \mathrm{Sr} /{ }^{86} \mathrm{Sr}$ ratio ranges from 0.70857 to 0.70888 , with an average value of 0.70871 . CS3g shows $\delta^{18} \mathrm{O}$ values ranging from -8.7 to $-4.1 \%$ VPDB, and $\delta^{13} \mathrm{C}$ between -1.2 and $+0.5 \%$ VPDB. Only one ${ }^{87} \mathrm{Sr} /{ }^{86} \mathrm{Sr}$ ratio was measured in CS3g, with a value of 0.70861 . The $\delta^{13} \mathrm{C}$ and ${ }^{87} \mathrm{Sr} /{ }^{86} \mathrm{Sr}$ values of CS3g are similar to that of CS3r, whereas their $\delta^{18} \mathrm{O}$ has slightly more depleted values.

\subsubsection{Penedès Basin}

Replacive dolomite RD1 of the Castellví outcrop yields $\delta^{18} \mathrm{O}$ values from -2.1 to $+1.2 \%$ VPDB, $\delta^{13} \mathrm{C}$ values from +1 to $+2.3 \%$ oPDB and an ${ }^{87} \mathrm{Sr} /{ }^{86} \mathrm{Sr}$ ratio of 0.707417 . The DS2 karst fill of the same outcrop has $\delta^{18} \mathrm{O}$ values varying from -1.8 to $+0.1 \%$ VPDB, $\delta^{13} \mathrm{C}$ ranging from -4.2 to $-2.9 \%$ VPDB and an ${ }^{87} \mathrm{Sr} /{ }^{86} \mathrm{Sr}$ ratio of 0.708761 . For the DS3 karst 
fill, the $\delta^{18} \mathrm{O}$ varies from -2 to $+0.7 \%$ VPDB, the $\delta^{13} \mathrm{C}$ ranges from -3.1 to $+0.1 \%$ VPDB, and the ${ }^{87} \mathrm{Sr} /{ }^{86} \mathrm{Sr}$ ratio is 0.708855 . CS1 has $\delta^{18} \mathrm{O}$ values ranging from -8.6 to $-8.5 \%$ VPDB and $\delta^{13} \mathrm{C}$ from -7.8 to $-7.6 \%$ VPDB.

Only the $\delta^{18} \mathrm{O}$ and $\delta^{13} \mathrm{C}$ was measured in samples from the Olèrdola and Montjuïc outcrops. $\delta^{18} \mathrm{O}$ and $\delta^{13} \mathrm{C}$ of CS2 from the Olèrdola outcrop range from -6.3 to -5.9 and from -4.7 to $-4.4 \%$ VPDB, respectively. For CS3, the $\delta^{18} \mathrm{O}$ and $\delta^{13} \mathrm{C}$ values range from -4.2 to -3.8 and from -4.1 to $-3.2 \%$ VPDB, respectively. The OP1 from the Montjuï outcrop has $\delta^{18} \mathrm{O}$ values ranging from -7.1 to $-4.4 \%$ VPDB and $\delta^{13} \mathrm{C}$ values from -10.3 to $-8.5 \%$ VPDB.

\section{Discussion}

\subsection{Detrital Versus Residual Origin of Karst Fills}

Lomando et al. [20] reported that the fill of the fracture and vug porosity of the Casablanca-1A well is composed of dolomitised micrite. These authors noted that this fill was red at the uppermost part of the wells and green at the bottom and reported the lower limit of the oxidant conditions between both colours. According to the characteristic colour, they called them terra rossa and terra verde fills.

The terms terra rossa (and terra verde) imply genetic conditions. According to the definition proposed by [41], the term terra rossa refers to meter-thick sequences of clays with kilometre extension that develop at the Earth surface associated with limestone karstification. Two different theories were proposed to explain the origin of these formations: a residual vs. a detrital origin. The residual origin hypothesis considers the terra rossa deposits as the insoluble residue that results from carbonate dissolution during karstification $[42,43]$. The main problem of this theory is the low content of clays and other insoluble minerals in limestones, which make it difficult to explain the large volumes of these fill accumulations. Contrarily, the detrital origin model assumes that the terra rossa sediment is composed of clayey detrital material, volcanic ash and/or aerial transported dust accumulated in pre-existent karst [44-46]. This theory, however, does not explain the close relationship between terra rossa and karsts and their simultaneous development. The authors of [41] proposed a third theory in which terra rossa is produced from the authigenic replacement of limestones by means of a reaction front of small dimensions. In this study, we did not use the terms terra rossa and terra verde in order to avoid any genetic implication and because the mineralogical and petrological characteristics of the studied fills in the Penedès Basin and València Trough do not fit with the original definition of terra rossa due to their high carbonate content.

The homogeneity of the mineralogy and petrology of the studied karst fills of the Casablanca and Amposta oil wells and of the Penedès Basin, as well as their proximity, make it unlikely that they were formed as independent materials and/or from different host rocks. The carbonate fraction of these fills is considered to have originated from the erosion of the host rock, either limestones or dolostones, which occurred during subaerial exposure during the Neogene extension period. This suggests a residual origin for the karst fills. Likewise, the fact that the non-carbonate fraction of the host limestones and fills of the Casablanca-1A well are constituted by the same minerals (illite, illite/smectite, quartz, pyrite and Ti oxides; [15]) also point out to a residual origin. There are two additional points in favour of this theory. The first one is that the bulk composition of the fills is enriched in the immobile elements ( $\mathrm{Ti}$ and $\mathrm{Al}$ ) with respect to the host limestone, according to the previous authors. The second point is the morphology of lath-shaped illite crystals as observed from the TEM images of Figure 5C, which do not show signs of mechanical deformation due to mineral transport. This could indicate that this mineral may have formed within the karst fills during diagenesis. In the same way, kaolinite in the Amposta Marino C2 well possibly precipitated from acidic fluids prior or during oil emplacement [16], whereas quartz and chlorite content could also provide from the dissolution of limestones. However, there is multiple evidence that indicates a detrital origin of the karst fills. For instance, the enrichment in immobile elements, such as Ti and 
$\mathrm{Al}$ of the fills with respect to their host carbonates is also interpreted as the input of external material during the formation of the fills [46]. Additionally, the illite coatings of Dolomite $2 \mathrm{~b}$ in the Casablanca-1A, well described by [15], are characteristic of the mechanical input of clays according to [47]. The presence of irregular flaky illite crystals in Dolomite $2 \mathrm{~b}$ supports this scenario. The presence of feldspar, quartz and irregular pyrite grains also accounts for a detrital influence during the accumulation of karst fills [15]. Similarly, feldspar grains in OP1 are identified by means of XRD at Montjuïc outcrop of the onshore Penedès Basin. The presence of illite, kaolinite and chlorite at this outcrop and in DS2 and DS3 from the Castellví outcrop could be of detrital origin. In such case, the source of feldspars, quartz and possibly clay minerals such as illite, kaolinite and chlorite could be the Palaeogene thrust sheets composed of Palaeozoic igneous rocks and metasediments of the Catalan Coastal Ranges (Figure 1). The unroofing of these thrust sheets fed the alluvial and fluvial systems filling the half grabens of the Catalan Margin [48-50]. The difference in the non-carbonate fraction content between the karst fills of the offshore València Trough and of the onshore Penedès Basin, and their host carbonates (from 2 to $9 \%$ for the fills vs. up to $1 \%$ for the host carbonates; [15]) suggest a detritic origin for the fills [10]. This implies the dissolution of an important volume of host limestone or dolostone and the subsequent accumulation of carbonate fills together with the input of external detrital non-carbonate minerals. The higher ${ }^{87} \mathrm{Sr} /{ }^{86} \mathrm{Sr}$ ratios of the studied fills with respect to their host rocks account for this scenario (Figure 13).

Therefore, based on all the aforementioned observations, we propose a polygenic origin for the studied fills, similar to the polygenic nature of the terra rossa fills $[1,45,46,51]$.

\subsection{Significance of the Colour of the Karst Fillls}

The reddish colour of rocks is due to the presence of Fe oxides and hydroxides either as free or forming a coating in clay minerals [52-54]. Contrarily, dark and grey colours are normally attributed to the presence of organic matter and / or Fe sulphides, whereas green colours are normally attributed to the $\mathrm{Fe}^{2+} / \mathrm{Fe}^{3+}$ ratio in chlorite and illite when other pigment phases are absent $[12,52,55]$. With respect to the clay minerals, especially those with a 2:1 structure as illite, Fe can be found as (1) $\mathrm{Fe}^{2+}$ and $\mathrm{Fe}^{3+}$ occurring in octahedral positions replacing $\mathrm{Al}$, and (2) adsorbed in the surface of clay particles as Fe oxides and hydroxides [56-59].

The colours of the studied karst fills of the Casablanca and Amposta oil fields, as well as in the Penedès basin, are attributed to their non-carbonate fraction. In these fills, no mineralogical or petrological differences were observed, except for the punctual presence of goethite crystals and the higher total Fe content in the reddish fills (Table 1). This Fe can be distributed between dolomite, pyrite, goethite and clays.

The data obtained by Mössbauer spectrometry on samples from the Casablanca oil field (Table 3 ) indicate that the predominant oxidation state of the Fe in host Dolomite $2 \mathrm{a}$ and Dolomite $2 \mathrm{~b}$ fills is $\mathrm{Fe}^{2+}$. However, the $\mathrm{Fe}^{2+} / \mathrm{Fe}^{3+}$ ratio in the reddish Dolomite $2 \mathrm{~b}$ is lower than in host Dolomite $2 \mathrm{a}$, suggesting that $\mathrm{Fe}^{2+}$ is from the dolomite host and $\mathrm{Fe}^{3+}$ from the non-carbonate fraction of the karst fills. Nanometre size particles of hematite (or hematite with a content lower than the detection limit of the analytical techniques that we use), which are disseminated or absorbed in the clay surface as red coatings, could be the source of the $\mathrm{Fe}^{3+}[58,60]$. This is supported by the presence of goethite crystals identified with TEM in the reddish Dolomite $2 b$ [15]. The $\mathrm{Fe}^{2+}$ of the ochre Dolomite $2 \mathrm{~b}$ is similar to that of its adjacent host Dolomite $2 \mathrm{a}$, indicating that $\mathrm{Fe}^{2+}$ could be derived from dolomite crystals. However, this does not rule out the contribution of illite. These results point out the high $\mathrm{Fe}^{2+}$ content of dolomite and possibly illite and, indirectly, the lack of pigment minerals such as hematite and goethite, as the main responsible of the ochre Dolomite $2 a$ and $2 b[52,55,58,59]$.

Intense red, pink and orange fills are found in the karstic formations of the onshore Penedès Basin. In general, DRX and Mössbauer spectra reveal the presence of hematite and goethite. Mössbauer spectrometry applied to the reddish DS2 dolomite from samples of the 
Castellví outcrop indicates the presence of hematite/goethite and possibly pyrite, although this can also be interpreted as $\mathrm{Fe}^{3+}$. The presence of such minerals, and possibly $\mathrm{Fe}^{3+}$, indicates a likely common origin for the reddish colours of fills of the onshore Penedès basin and the offshore València Trough (e.g., Casablanca and Amposta oil fields). Accordingly, OP1 of the Montjuïc outcrop shows similarities with the ochre fills in the Casablanca oil field. Mössbauer spectra of this fill indicate the presence of $\mathrm{Fe}^{2+}$ and pyrite, probably ruling out the presence of $\mathrm{Fe}^{3+}$ and pigment minerals such as hematite and goethite. The greenish fills of the Amposta oil field (CS3g) could indicate variations in the $\mathrm{Fe}^{2+} / \mathrm{Fe}^{3+}$ ratio in chlorite and illite in the absence of other pigment phases [52,55].

\subsection{Depositional Environment of Karst Fills}

The isotopic and elemental composition of karst fills compared with that of their host carbonates reflect the input of external fluids and organic components as well as diagenetic processes. Their $\delta^{13} \mathrm{C}$ and ${ }^{87} \mathrm{Sr} /{ }^{86} \mathrm{Sr}$ isotope geochemistry are, in general, different from that of their adjacent Mesozoic host carbonates (Figures 10 and 11). For example, karst fills from the Amposta Marino C2 well and Penedès Basin have depleted $\delta^{13} \mathrm{C}$ values with respect to their adjacent host rocks (Figure 12), probably indicating the input of soil-derived $\mathrm{CO}_{2}$ during the subaerial exposure of Mesozoic carbonates [61,62]. This interpretation agrees with the study of [61], which concluded that paedogenic carbonates have $\delta^{13} \mathrm{C}$ values between -10 and $+2 \%$ VPDB. Accordingly, the lighter $\delta^{13} \mathrm{C}$ of fills in the exposed outcrops of the Penedès Basin supports a meteoric scenario for their accumulation, whereas the values of fills in the offshore Amposta well are also within the range of paedogenic carbonates. Contrarily, the similar $\delta^{13} \mathrm{C}$ values of dolomite $1,2 \mathrm{a}$ and $2 \mathrm{~b}$ from the Casablanca oil well are interpreted by [15] as the result of a similar dolomitising fluid interacting with host rocks and karst fills. The ${ }^{87} \mathrm{Sr} /{ }^{86} \mathrm{Sr}$ ratios of all the karst fills show higher ratios than their adjacent host rocks and Late Jurassic-Early Cretaceous seawater, suggesting the influence of a more radiogenic source or Burdigalian-Langhian seawater, as indicated in Figure 13. Alternatively, the higher ${ }^{87} \mathrm{Sr} /{ }^{86} \mathrm{Sr}$ ratios of Dolomite $2 \mathrm{a}$ and $2 \mathrm{~b}$ from the Casablanca-1A well with respect to those of Dolomite 1 could be the result of clay leaching during dolomitisation of these fills, according to [15]. The $\delta^{18} \mathrm{O}$ isotopic composition of most of the karst fills has similar values to that of their adjacent host rocks, indicating a local origin of the carbonate fraction. Contrarily, CS3r and CS3g in the Amposta oil well and CS1 in the Castellví outcrop have more depleted $\delta^{18} \mathrm{O}$ values than those of their host carbonates. This depletion is interpreted at the Amposta oil well as resulting from the recrystallisation of CS3r and CS3g fills from evolved meteoric waters [16], although an influence of hot fluids cannot be ruled out. Contrarily, [3] interpreted that CS1 of the Castellví outcrop precipitated from meteoric fluids, based on a large dataset of geochemical data of fracture-filling carbonates and karst fills sampled throughout the Penedès Basin. Regarding the elemental composition of karst fills, the higher Mn content of the fills from the onshore Penedès Basin with respect to those of the offshore Casablanca and Amposta oil wells could indicate a greater influence of meteoric fluids onshore [63]. Moreover, the decrease in Mg of the Castellví outcrop from RD1 to CS1 could indicate a progressive increase in meteoric fluids or a change in the host-carbonate feeding the karst system.

The oxidation state of Fe in a rock is indicative of the Eh- $\mathrm{pH}$ conditions of the depositional/diagenetic medium in which karst fills accumulated. The high total Fe content, together with the presence of $\mathrm{Fe}^{3+}$, in the structure of illite or possibly in oxides and iron hydroxides, suggests that reddish fills were formed under oxidising (and perhaps slightly acidic) conditions (Figure 14A). On the other hand, the dominance of $\mathrm{Fe}^{2+}$ in ochre fills responds to reductive conditions (Figure 14B), leading to reduction and dissolution of oxides and hydroxides and partial leaching of $\mathrm{Fe}^{3+}$ contained in the structure of illite. The change in redox conditions affecting the oxidation state of Fe in the karst fills could be related to water table fluctuations. A similar scenario was inferred to explain different calcite cement generations during the early-middle Miocene in syn-rift deposits filling the onshore Penedès half-graben [64]. 


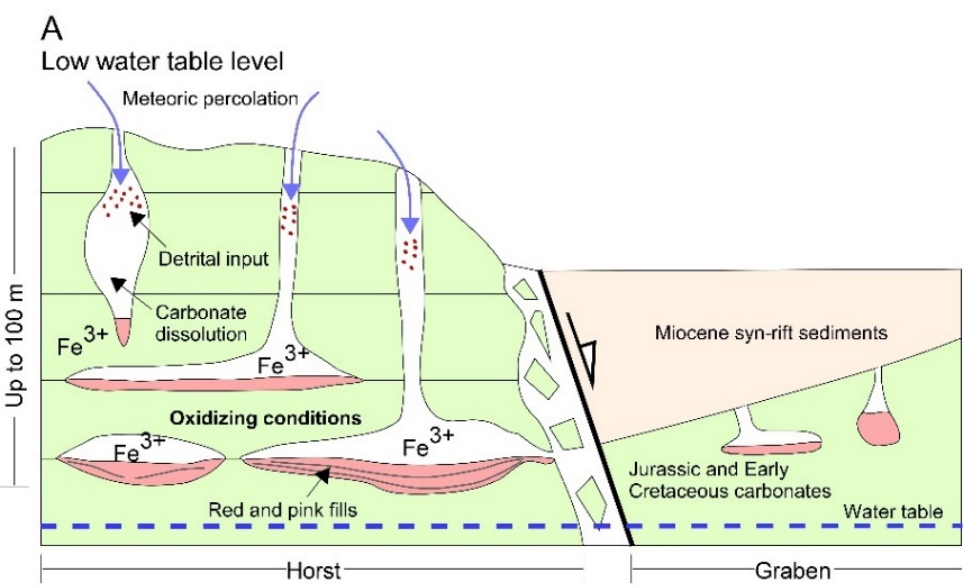

B

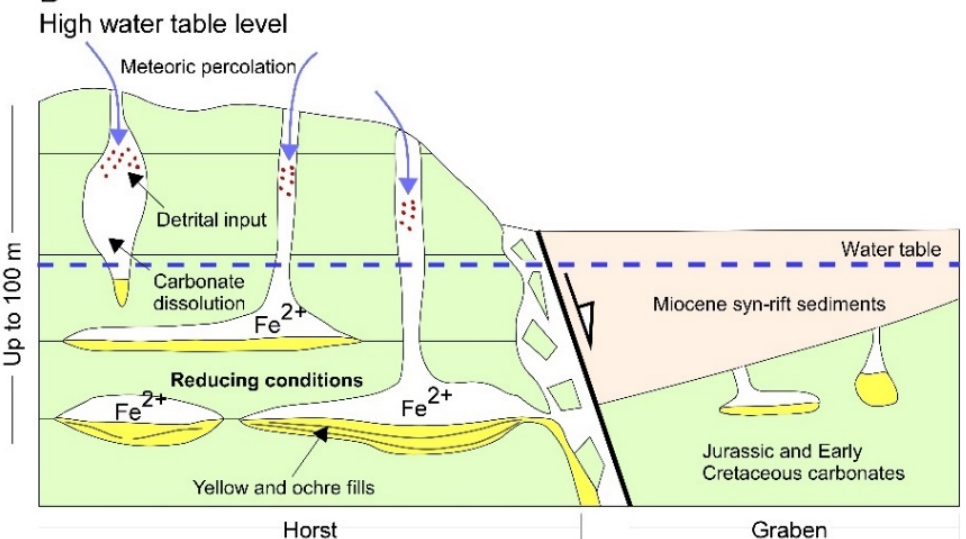

Figure 14. Sketch showing the two scenarios of karst fill accumulation in carbonates in the Penedès Basin and Amposta Marino C2 and Casablanca-1A oil wells. (A) Low water table level characterised by oxidising conditions and accumulation of red to pink fills. (B) High water table level characterised by more reducing conditions and accumulation of yellow to ochre fills. In both scenarios, carbonate dissolution and meteoric and detrital input occur. Later dolomitisation of karst fills of the Casablanca$1 \mathrm{~A}$ well is not represented in this figure. The penetration of the karst system at depth is based on the distribution of karst fills from the Casablanca-1A and Amposta Marino C2 wells [15,16].

Another parameter affecting the changes in the Eh-pH conditions that facilitated the release of Fe cations controlling the colour of karst fills of the Penedès Basin and València Trough could be the presence of organic matter. Suboxic and moderately acidic conditions in specific areas of the karst system, below the water table level, and where groundwaters become stagnant (e.g., in unconnected siphons or pothooks), facilitated the leaching of Fe3+, the lack of host carbonate dissolution and the preservation of organic matter trapped in rocks. After dissolution and karst development due to a change in the karst system dynamics, organic matter can be accumulated in karstic cavities. The existence of suboxic and reducing environments in karstic systems could explain the accumulation of greenish fills, as described by [65]. This scenario would be compatible with the presence of Jurassic dolostones in the Garraf Horst bounding the onshore Penedès Basin, with a total organic carbon content (TOC) between 0.02 and $0.82 \%$ [66]. These organic-rich dolostones are equivalent to those described in the Casablanca C1 and Amposta Marino C2 oil wells.

\section{Conclusions}

The origin of the colour of karst fills of the onshore Penedès Basin and offshore València Trough as well as their detrital vs. residual origin, and the depositional environment was deciphered integrating spectral, mineralogical and geochemical methods, leading to the following conclusions: 
1. Karst fills of the Penedès Basin and València Trough have red to pink, ochre, green and orange colours. The main mineralogy of these fills is calcite and dolomite, with minor contents of illite, smectite, kaolinite, chlorite, quartz, feldspar and pyrite;

2. Mössbauer spectrometry of karst fills and adjacent host carbonates indicate that, in general, Fe3+ from goethite is the dominant species in reddish fills, whereas Fe2+ from dolomite is dominant in the ochre to orange fills;

3. The carbonate fraction of karst fills is considered to have originated from the erosion of their host carbonates (limestones and dolostones). The non-carbonate fraction, which consists of illite (authigenic and as grain coatings), kaolinite, smectite, pyrite (authigenic and of irregular shape), quartz and feldspar, accounts for a polygenic origin of the karst fills (detrital and residual);

4. The lower $813 \mathrm{C}$ values and higher $87 \mathrm{Sr} / 6 \mathrm{Sr}$ ratios of most of the karst fills with respect to their adjacent host rocks could indicate the input of soil-derived $\mathrm{CO} 2$ together with the input of an external radiogenic source into the karstic system;

5. The higher Mn content of the onshore Penedès Basin fills with respect to those of the offshore Casablanca and Amposta oil wells could indicate a greater influence of meteoric fluids in the former. The decrease in Mg in the Castellví outcrop from RD1 to CS1 can also be interpreted as a progressive increase in meteoric percolation in the karst system or a change in the host-carbonate feeding the karst system;

6. The reddish colours of the fills result from the presence of pigment minerals such as hematite and goethite, as well as the dominance of the Fe3+ species, whereas the ochre and orange colours are attributed to the dominance of Fe2+. The greenish colours could result from fluctuations in the $\mathrm{Fe} 3+/ \mathrm{Fe} 2+$ ratio;

7. The variation in colour of the karst fills is attributed to fluctuations in the water table, which control the $\mathrm{Eh} / \mathrm{pH}$ conditions in the karst system. Thus, reddish colours are attributed to lower water table level and oxidising episodes, and orange and ochre ones to high water table level and more reducing episodes.

Supplementary Materials: The following are available online at https: / www.mdpi.com/article / $10.3390 / \min 11121382 / s 1$, Table S1: Mg, Mn, Fe and Sr contents in ppm of the karst fills and host carbonates in the Casablanca and Amposta oil wells and in the Penedès Basin. Table S2: $\delta^{18} \mathrm{O}$ and $\delta^{13} \mathrm{C}$ values of the karst fills and host carbonates of the Casablanca and Amposta oil wells and of the Penedès Basin. Table S3: ${ }^{87} \mathrm{Sr} /{ }^{86} \mathrm{Sr}$ ratios of the karst fills and host carbonates of the Casablanca and Amposta oil and of the Castellví outcrop in the Penedès Basin.

Author Contributions: Conceptualisation, A.T. and E.P.; methodology, A.T., E.P., N.R.-M., V.B., D.C., L.C. and J.D.M.-M.; software, D.C.; validation, D.C. and A.T.; formal analysis, N.R.-M. and V.B.; investigation, V.B. and N.R.-M.; writing-original draft preparation, N.R.-M. and A.T.; writingreview and editing, D.C., I.C., M.M. and E.G.-R.; supervision, E.P. and A.T.; funding acquisition, A.T. and E.P. All authors have read and agreed to the published version of the manuscript.

Funding: The presented research was supported by the DGICYT Spanish Project PGC2018-093903B-C22 and PID2020-118999GB-I00 and by the Catalan Council to the Grup Consolidat de Recerca "Geologia Sedimentària" (2017SGR-824). EGR acknowledges the funding provided by the Spanish Ministry of Science, Innovation and Universities ("Ramón y Cajal" fellowship RYC2018-026335-I).

Acknowledgments: This research was performed within the framework of DGICYT Spanish Projects PGC2018-093903-B-C22 and PID2020-118999GB-I00 funded by the Ministerio de Ciencia, Innovación y Universidades/Agencia Estatal de Investigación/Fondo Europeo de Desarrollo Regional. EGR acknowledges the funding provided by the Spanish Ministry of Science, Innovation and Universities ("Ramón y Cajal” fellowship RYC2018-026335-I). The isotopic, electron microprobe and XRD analyses and the SEM and TEM observations were carried out at "Centres Científics i Tecnològics" of the Universitat de Barcelona. Mössbauer spectroscopy analyses were carried out at Institut de Ciència de Materials de Barcelona. Strontium isotope analyses were carried out at "CAI de Geocronología y Geoquímica Isotópica" of the Universidad Complutense de Madrid. 
Conflicts of Interest: The authors declare no conflict of interest. The funders had no role in the design of the study; in the collection, analyses, or interpretation of data; in the writing of the manuscript, or in the decision to publish the results.

\section{References}

1. Šušteršič, F.; Rejšek, K.; Mišič, M.; Eichler, F. The role of loamy sediment (terra rossa) in the context of steady state karst surface lowering. Geomorphology 2009, 106, 35-45. [CrossRef]

2. White, W.B. Cave sediments and paleoclimate. J. Cave Karst Stud. 2007, 69, 76-93.

3. Baqués, V.; Travé, A.; Cantarero, I. Development of successive karstic systems within the Baix Penedès Fault zone (onshore of the Valencia Trough, NW Mediterranean). Geofluids 2014, 14, 75-94. [CrossRef]

4. Baqués, V.; Ukar, E.; Laubach, S.E.; Forstner, S.R.; Fall, A. Fracture, Dissolution, and Cementation Events in Ordovician Carbonate Reservoirs, Tarim Basin, NW China. Geofluids 2020, 2020, 9037429. [CrossRef]

5. Geet, M.V.; Swennen, R.; Durmishi, C.; Roure, F.; Muchez, P. Paragenesis of Cretaceous to Eocene carbonate reservoirs in the Ionian fold and thrust belt (Albania): Relation between tectonism and fluid flow. Sedimentology 2002, 49, 697-718.

6. Hajna, N.Z.; Bosák, P.; Pruner, P.; Mihevc, A.; Hercman, H.; Horáček, I. Karst sediments in Slovenia: Plio-Quaternary multi-proxy records. Quat. Int. 2020, 546, 4-19. [CrossRef]

7. Esteban, M.; Klappa, C.I. Subaerial exposure environments. In Carbonate Depositional Environments; Scholle, P.A., Bebout, D.G., Moore, C.H., Eds.; American Association Petroleum Geologists: Tulsa, OK, USA, 1983; pp. 1-54.

8. Beukes, N.J.; Dorland, H.; Gutzmer, J.; Nedachi, M.; Ohmoto, H. Tropical laterites, life on land, and the history of atmospheric oxygen in the Paleoproterozoic. Geology 2002, 30, 491-494. [CrossRef]

9. Iacovello, F.; Martini, I. Clay minerals in cave sediments and terra rossa soils in the Montagnola Senese karst massif (Italy). Geol. Quaterly 2013, 57, 527-536. [CrossRef]

10. Iacovello, F.; Martini, I. Provenance and geological significance of red mud and other clastic sediments of the Mugnano Cave (Montagnola Senese, Italy). Int. J. Speleol. 2012, 31, 317-328. [CrossRef]

11. Alonso-Zarza, A.M.; Jones, B. Root calcrete formation on Quaternary karstic surfaces of Grand Cayman. Geol. Acta 2007, 5, 77-88.

12. Fornós, J.J.; Ginés, J.; Gràcia, F. Present-day sedimentary facies in the coastal karst caves of Mallorca Island (Western Mediterranean). J. Cave Karst Stud. 2009, 71, 86-99.

13. Roca, E.; Sans, M.; Cabrera, L.; Marzo, M. Oligocene to Middle Miocene evolution of the central Catalan margin (northwestern Mediterranean). Tectonophysics 1999, 315, 209-229. [CrossRef]

14. Travé, A.; Calvet, F.; Soler, A.; Labaume, P. Fracturing and fluid migration during Paleogene compression and Neogene extension in the Catalan Coastal Ranges, Spain. Sedimentology 1998, 45, 1063-1082. [CrossRef]

15. Rodríguez-Morillas, N.; Playà, E.; Travé, A.; Martín-Martín, J.D. Diagenetic processes in a partially dolomitized carbonate reservoir: Casablanca oil field, Mediterranean Sea, offshore Spain. Geol. Acta 2013, 11, 195-214.

16. Playà, E.; Travé, A.; Caja, M.A.; Salas, R.; Martín-Martín, J.D. Diagenesis of the Amposta offshore oil reservoir (Amposta Marino C2 well, Lower Cretaceous, Valencia Trough, Spain). Geofluids 2010, 10, 314-333. [CrossRef]

17. Baqués, V.; Travé, A.; Roca, E.; Marín, M.; Cantarero, I. Geofluid behaviour in successive extensional and compressional events: A case study from the southwestern end of the Vallès-Penedès Fault (Catalan Coastal Ranges, NE Spain). Pet. Geosci. 2012, 18, 17-31. [CrossRef]

18. Baqués, V.; Travé, A.; Benedicto, A.; Labaume, P.; Cantarero, I. Relationships between carbonate fault rocks and fluid flow regime during propagation of the Neogene extensional faults of the Penedès basin (Catalan Coastal Ranges, NE Spain). J. Geochem. Explor. 2010, 106, 24-33. [CrossRef]

19. Esteban, M. Paleokarst: Case histories. In Paleokarsts and Paleokarstic Reservoirs; Wright, V.P., Esteban, M., Smart, P.L., Eds.; Postgraduate Research Institute for Sedimentology, University of Reading PRIS Contribution: Reading, UK, 1991; Volume 152, pp. 20-46.

20. Lomando, A.J.; Harris, P.M.; Orlopp, D.E.; Fritz, R.D.; Wilson, J.L.; Yurewicz, D.A. Casablanca Field, Tarragona Basin, Offshore Spain: A Karsted Carbonate Reservoir. In Paleokarst Related Hydrocarbon Reservoirs; SEPM Society for Sedimentary Geology: Broken Arrow, OK, USA, 1993; Volume 18.

21. Baqués, V.; Travé, A.; Benedicto, A.; Labaume, P. Relationship between fluid flow and tectonic brecciation in the Neogene extensional Vallès-Penedès basin (Catalan Ranges, NE Iberian). J. Geochem. Explor. 2009, 101, 4. [CrossRef]

22. Bartrina, M.T.; Cabrera, L.; Jurado, M.J.; Guimerà, J.; Roca, E. Evolution of the central Catalan margin of the Valencia trough (western Mediterranean). Tectonophysics 1992, 203, 219-247. [CrossRef]

23. Roca, E.; Guimerà, J. The Neogene structure of the eastern Iberian margin: Structural constraints on the crustal evolution of the Valencia trough (western Mediterranean). Tectonophysics 1992, 203, 203-218. [CrossRef]

24. Roca, E. La evolución geodinámica de la Cuenca Catalano-Balear y áreas adyacentes desde el Mesozoico hasta la actualidad. Acta Geol. Hisp. 1994, 29, 3-25.

25. Marín, M.; Roca, E.; Marcuello, A.; Cabrera, L.; Ferrer, O. Mesozoic structural inheritance in the Cenozoic evolution of the central Catalan Coastal Ranges (western Mediterranean): Structural and magnetotelluric analysis in the Gaià-Montmell High. Tectonophysics 2021, 814, 228970. [CrossRef] 
26. Cabrera, L.; Roca, E.; Garcés, M.; Porta, J.d. Estratigrafía y evolución tectonosedimentaria oligocena superior-neógena del sector central del margen catalán (Cadena Costero-Catalana). In Geología de España; Vera, J.A., Ed.; Sociedad Geológica de España; Instituto Geológico y Minero de España: Madrid, Spain, 2004; pp. 569-572.

27. Clavell, E.; Berastuegui, X. Petroleum Geology of the Gulf of València. In Generation, Accumulation and Production of Europe's Hydrocarbons; Spencer, A.M., Ed.; European Association of Petroleum Geologists: Oxford, UK, 1991; Volume 1, pp. $355-368$.

28. Agustí, J.; Cabrera, L.; Moya, S. Sinopsis estratigráfica del Neógeno en la fosa del Vallès-Penedès. Paleontol. Evol. 1985, $18,57-81$.

29. Cabrera, L.; Calvet, F. Onshore Neogene record in NE Spain: Vallès-Penedès and el Camp half-grabens (NW Mediterranean). In Tertiary Basins of Spain; Friend, P.T., Abrio, C.T., Eds.; Cambridge University Press: Cambridge, MA, USA, 1996; pp. 97-105.

30. Demaison, G.; Bourgeois, F.T. Environment of deposition of Middle Miocene (Alcanar) Carbonate Source Beds, Casablanca Field, Tarragona Basin, Offshore Spain. In Petroleum Geochemistry and Source Rock Potential of Carbonate Rocks; Palacas, J.G., Ed.; American Association of Petroleum Geologists Studies in Geology: Tulsa, OK, USA, 1984; Volume 18, pp. 151-161.

31. Permanyer, A.; Salas, R. Integrated thermal model, diagenetic history and oil correlation in western Mediterranean, Spain. In Proceedings of IV ALAGO Workshop on Basin Modelling, Buenos Aires, Argentina, 16-19 October 2005.

32. Arasa-Tuliesa, A.; Cabrera, L. Neogene-Quaternary onshore record in the lower Ebro river incised palaeovalley (Ebro margin, Catalan Coastal Range, NE Iberia). Geol. Acta 2018, 16, 265-292. [CrossRef]

33. Watson, H.J. Casablanca Field Offshore Spain, a Paleogeomorphic Trap. In The Deliberate Search for the Subtle Trap; American Association of Petroleum Geologists: Tulsa, OK, USA, 1982; Volume 32, pp. 237-250.

34. Baqués, V. Diagenesis and Fluid-Fracture Evolution in an Intracontinental Basin: The Penedès Half-Graben, Western Mediterranean. Ph.D. Thesis, Universitat de Barcelona, Barcelona, Spain, 2012; 110p.

35. Seemann, U.; Pümpin, V.F.; Casson, V.F. Amposta oil field. In American Association of Petroleum Geologists Treatise of Petroleum Geology. Atlas of Oil and Gas Fields; American Association of Petroleum Geologists: Tulsa, OK, USA, 1990; Volume A-017, pp. 1-20.

36. Salas, R. El Malm i el Cretaci Inferior Entre el Massís de Garraf i La Serra d'Espadà. Ph.D. Thesis, Universitat de Barcelona, Barcelona, Spain, 1987.

37. McCrea, J.M. On the Isotopic Chemistry of Carbonates and a Paleotemperature Scale. J. Chem. Phys. 1950, 18, 849-957.

38. Craig, H.; Gordon, I.-I. Deuterium and oxygen-18 variations in the ocean and the marine atmosphere. In Stable Isotopes in Oceanographic Studies and Paleotemperatures, Spoleto, July 26th-30th, 1965; Tongiorgi, E., Ed.; Consiglio Nazionale delle Richerche, Laboratorio di Geologia Nucleare: Pisa, Italy, 1965; pp. 9-130.

39. Claypool, G.E.; Kaplan, W.T.; Kaplan, I.R.; Sakai, H.; Zak, I. The age curves of sulfur and oxygen isotopes in marine sulfate and their mutual interpretations. Chem. Geol. 1980, 28, 199-260.

40. McArthur, J.M.; Howarth, R.J.; Bailey, T.R. Strontium Isotope Stratigraphy: LOWESS Version 3: Best Fit to the Marine Sr-Isotope Curve for 0-509 Ma and Accompanying Look-up Table for Deriving Numerical Age. J. Geol. 2001, 109, $155-170$.

41. Merino, E.; Banerjee, A. Terra Rossa Genesis, Implications for Karst, and Eolian Dust: A Geodynamic Thread. J. Geol. 2008, 116, 62-75. [CrossRef]

42. Thornbury, W.D. Principles of Geomorphology; John Wiley \& Sons: New York, NY, USA; London, UK, 1954.

43. Moresi, M.; Mongelli, G. The relation between the terra rossa and the carbonate-free residue of the underlying limestones and dolostones in Apulia, Italy. Clay Miner. 1988, 23, 439-446. [CrossRef]

44. Olson, C.G.; Ruhe, R.V.; Mausbach, M.J. The Terra Rossa Limestone Contact Phenomena in Karst, Southern Indiana. Soil Sci. Soc. Am. J. 1980, 44, 1075-1079. [CrossRef]

45. Durn, G. Terra rossa in the Mediterranean region: Parent materials, composition and origin. Geol. Croat. 2003, 56, 83-100.

46. Durn, G.; Ottner, F.; Slovenec, D. Mineralogical and geochemical indicators of the polygenetic nature of terra rossa in Istria, Croatia. Geoderma 1999, 91, 125-150. [CrossRef]

47. Moraes, M.A.S.; Ros, L.F.d. Infiltrated clays in fluvial Jurassic sandstones of Reconcavo Basin, northeastern Brazil. J. Sediment. Res. 1990, 60, 809-819. [CrossRef]

48. Parcerisa, D.; Gómez-Gras, D.; Travé, A. A model of early calcite cementation in alluvial fans: Evidence from the Burdigalian sandstones and limestones of the Vallès-Penedès half-graben (NE Spain). Sediment. Geol. 2005, 178, 197-217. [CrossRef]

49. Parcerisa, D.; Gómez-Gras, D.; Travé, A.; Martín-Martín, J.D.; Maestro, E. Fe and Mn in calcites cementing red beds: A record of oxidation-reduction conditions: Examples from the Catalan Coastal Ranges (NE Spain). J. Geochem. Explor. 2006, 89, 318-321. [CrossRef]

50. Parcerisa, D.; Gómez-Gras, D.; Roca, E.; Madurell, J.; Agustí, J. The Upper Oligocene of Montgat (Catalan Coastal Ranges, Spain): New age constraints to the western Mediterranean Basin opening. Geol. Acta 2007, 5, 3-17.

51. Delgado, R.; Martín-García, J.M.; Oyonarte, C.; Delgado, G. Genesis of the terra rossa of Sierra de Gádor, Almería, Spain. Eur. J. Soil Sci. 2003, 54, 1-16.

52. McBride, E.F. Significance of color in red, green, purple, olive, brown, and gray beds of Difunta Group, northeastern Mexico. J. Sediment. Res. 1974, 44, 760-773. [CrossRef]

53. Torrent, J.; Schwertmann, U. Influence of hematite on the color of red beds. J. Sediment. Res. 1987, 57, 682-686. [CrossRef]

54. Eren, M.; Kadir, S. Colour genesis of Upper Cretaceous pelagic red sediments within the Eastern Pontides, NE Turkey. Yerbilimleri 2001, 24, 71-79.

55. Keller, W.D. Illite and montmorillonite in green sedimentary rocks. J. Sediment. Res. 1953, 23, 3-9. [CrossRef] 
56. Goodman, B.A. Chapter 5 Mossbauer Spectroscopy. In Developments in Sedimentology; Fripiat, J.J., Ed.; Elsevier: Amsterdam, The Netherlands, 1982; Volume 34, pp. 113-137.

57. Velde, B. Composition and Mineralogy of Clay Minerals. In Origin and Mineralogy of Clays: Clays and the Environment; Velde, B., Ed.; Springer: Berlin/Heidelberg, Germay, 1995; pp. 8-42. [CrossRef]

58. Casas, L.; Parcerisa, D.; Gómez-Gras, D.; Calvet, F.; Roig, A.; Molins, E. Mössbauer spectrometry to study diagenetical processes of red beds and sand dikes in the Vallès-Penedès half graben. In Hyperfine Interactions (C); Thomas, M.F., Williams, J.M., Gibb, T.C., Eds.; Kluver Academic Publishers: Amsterdam, The Netherlands, 2003; Volume 5, pp. 393-396.

59. Matsuo, M.; Kubo, K.; Isozaki, Y. Mössbauer spectroscopic study on characterization of iron in the Permian to Triassic deep-sea chert from Japan. In Hyperfine Interactions (C); Thomas, M.F., Williams, J.M., Gibb, T.C., Eds.; Kluver Academic Publishers: Amsterdam, The Netherlands, 2003; Volume 5, pp. 435-438.

60. Worden, R.H.; Morad, S. Clay Minerals in Sandstones: Controls on Formation, Distribution and Evolution. In Clay Mineral Cements in Sandstones; Wiley-Blackwell: Hoboken, NJ, USA, 1999; pp. 1-41. [CrossRef]

61. Cerling, T.E.; Quade, J.; Wang, Y.; Bowman, J.R. Carbon isotopes in soils and palaeosols as ecology and palaeoecology indicators. Nature 1989, 341, 138-139.

62. Moore, C. Carbonate reservoirs: Porosity evolution and diagenesis in a sequence stratigraphic framework. Dev. Sedimentol. 2001, 55,444 .

63. Webb, G.E.; Nothdurft, L.D.; Kamber, B.S.; Kloprogge, J.T.; Zhao, J.X. Rare earth element geochemistry of scleractinian coral skeleton during meteoric diagenesis: A sequence through neomorphism of aragonite to calcite. Int. Assoc. Sedimentol. 2009, 56, 1433-1463. [CrossRef]

64. Travé, A.; Calvet, F. Syn-rift geofluids in fractures related to the early-middle Miocene evolution of the Vallès-Penedès half-graben (NE Spain). Tectonophysics 2001, 336, 101-120. [CrossRef]

65. Esteban, M.; Wilson, J.L. Introduction to Karst Systems and Paleokarst Reservoirs. In Paleokarst Related Hydrocarbon Reservoirs; Fritz, R.D., Wilson, J.L., Yurewicz, D.A., Eds.; SEPM Society for Sedimentary Geology: Broken Arrow, OK, USA, 1993 ; Volume 18.

66. Playà, E. Garraf Project: Breached Oil Field or Carrier in Jurassic Dolomites. Nor. Hydro Intern. Rep. 1998, unpublished. 